\title{
Protecting Minority Shareholders in Blockholder-Controlled Companies - Evaluating the UK's Enhanced Listing Regime in \\ Comparison with Investor Protection Regimes in New York and Hong Kong
}

\section{Roger Barker* and Iris H-Y Chiu**}

\section{Introduction}

The London Stock Exchange is a vibrant capital market which attracts issuers from all over the world, bringing companies with diverse corporate governance practices and norms into the UK listed landscape. The dominant mode of corporate governance in UK public companies has historically been dispersed ownership. ${ }^{1}$ However, during the last decade or so, the UK Listing regime has found itself addressing unfamiliar governance issues arising at companies with a concentrated ownership structure. Such companies have typically originated from the natural resources/mining sectors of various developing economies, and initially appealed to investors due to their strong growth prospects. ${ }^{2}$ Unfortunately, a series of high profile scandals at Bumi (now renamed Asia Mineral Resources), Eurasian Natural Resources Corporation (now de-listed) and Essar Energy, have tarnished the reputation of such foreign listings and led the UK Listing Authority (the Financial Conduct Authority) to introduce new corporate governance standards as part of its Listing Regime for companies with controlling shareholders (thereafter 'The Enhanced Listing Regime'). The new rules came into force in May $2014 .^{3}$

The Enhanced Listing Regime is essentially a measure of minority shareholder protection. It introduces several prescriptive corporate governance standards to protect minority shareholders in blockholder-controlled companies. These standards are novel in nature compared to the corporate governance standards that have been developed thus far in the UK and in other key listing regimes.

Minority shareholder protections are important to listing regimes due the importance of legal and regulatory frameworks to economic and financial development. Although the

\footnotetext{
*Director of Corporate Governance and Professional Standards, Institute of Directors.

**Reader in Laws, Faculty of Laws, University College London.

${ }^{1}$ Brian R Cheffins, Corporate Ownership and Control: British Businesses Transformed (Oxford: Oxford University Press, 2010); Janette Rutterford, 'The Shareholder Voice: British and American Accents, 1890-1965' (2012) 13 Enterprise and Society 120.

2 Brian R Cheffins, 'The Undermining of UK Corporate Governance?' (2013) at http://ssrn.com/abstract id=2129686.

${ }^{3}$ Financial Conduct Authority, Enhancing the Effectiveness of the Listing Regime and Further Consultation (November 2013).
} 
original La Porta et al thesis connecting law and finance ${ }^{4}$ has since been criticised for its broad brush approach, various methodological inadequacies ${ }^{5}$ and incongruence with empirical data, ${ }^{6}$ most commentators acknowledge that 'law matters' to certain extents in different contexts. ${ }^{7}$

We analyse how the Enhanced Listing Regime works as a minority protection mechanism in blockholder-controlled companies. In the context of the UK equity market, developing standards for the governance of such companies is relatively unchartered territory. We therefore place the FCA's pioneering efforts in the wider context of minority protection frameworks in global capital markets and engage in a comparative analysis to see if lessons can be learnt from elsewhere.

Section A provides an overview of the Enhanced Listing Regime, and considers how and whether it addresses the governance issues arising out of block-held structures. We then undertake a comparison of the UK regime with the regimes in the New York and Hong Kong listed markets, focusing on the New York Stock Exchange (NYSE) in Section B and Stock Exchange of Hong Kong (SEHK) in Section C. These two regimes do not have dedicated standards to protect minority shareholders in block-held companies, but our comparative study is undertaken at a broad level to assess the nature and importance of minority protection frameworks in these leading capital markets.

We have chosen the NYSE and SEHK as comparative subjects as they are significant global markets for equities, albeit with certain key differences. New York and Hong Kong are located within the Anglo-Saxon legal tradition of minority shareholder protection. However, the NYSE is a market which, although mainly composed of companies with dispersed ownership, also features some high profile block-held listed companies which have not, so far, raised significant concerns among the investment community. In contrast, the SEHK has a substantial proportion of blockholder-controlled companies with governance issues that are often similar to those that have recently confronted the LSE. Section D draws together our final observations and conclusions.

\footnotetext{
${ }^{4}$ that the adequacy of legal protection for minority shareholders affects the stock market development of a given country, the quality of such laws being rooted in legal origins, see R La Porta, F Lopez-de-Silanes, A Shleifer and R Vishny, 'Law and Finance' (1998) 106 Journal of Political Economy 1113.

${ }^{5}$ Holger Spamann, 'The “Antidirector Rights Index" Revisited' (2010) 23 Review of Financial Studies 467.

${ }^{6}$ See Section D.

${ }^{7}$ Such as Brian R Cheffins, 'Law as Bedrock: The Foundations of an Economy Dominated by Widely Held Public Companies' (2003) 23 Oxford Journal of Legal Studies 1; Ruth V Aguilera and Cynthia A Williams, "Law and Finance': Inaccurate, Incomplete, and Important' (2009) at http://ssrn.com/abstract=1523895.
} 


\section{A. Examining the Enhanced Listing Regime within the UK Minority Shareholder Protection Framework}

\section{The Framework for Minority Shareholder Protection in the UK}

Company law and securities regulation address different aspects of minority investor protection on listed markets. Minority shareholder protection regimes appear to be highly valued by investors, although work remains to be done in establishing their causal significance - whether in relation to corporate performance, investment portfolio performance, and at a broader level, market and economic development. ${ }^{8}$

Although majority shareholder rule is widely seen as a legitimate basis for the exercise of power in the democracy of corporate capitalism, 'the tyranny of the majority' is a potential concern. Controlling shareholders are potentially able to expropriate resources from minority shareholders via a variety of mechanisms, most of which stem from their ability to control the appointment of the board of directors and pass resolutions at General Meetings.

These mechanisms can, for example, take the form of appointing or rewarding senior managers on the basis of family rather than meritocratic considerations or influencing company strategy in a way that promotes blockholders' personal idiosyncratic objectives. More egregiously, the controlling shareholder can use their position of influence to facilitate related party transactions, asset stripping or outright theft from the company. These 'private benefits of control' are generally achieved at the expense of the net wealth of minority shareholders, and allow blockholders to benefit disproportionately from their control of a majority (or significant minority) of the voting shares of the entity. ${ }^{9}$

In the UK, minority shareholder protection had humble beginnings ${ }^{10}$ in company law. Even today, the disadvantage of being in the minority can only be countervailed by law to a modest extent. Minority shareholder protection became more developed in the $1980 \mathrm{~s}^{11}$ with the rise of securities regulation. ${ }^{12}$ Corporate transparency is a key objective of securities regulation and continued to be emphasised in the 1990s, although minority

\footnotetext{
${ }^{8}$ Inessa Love, 'Corporate Governance and Performance around the World: What We Know and What We Don't' (The World Bank Research Observer 2010).

${ }^{9}$ Roger M. Barker, Corporate Governance, Competition, and Political Parties: Explaining Corporate Governance Change in Europe (Oxford: OUP 2010), p.38.

${ }^{10}$ The derivative action as an exception to Foss $v$ Harbottle, and the delicate balance struck in early $20^{\text {th }}$ century case law starting with Allen $v$ Gold Reefs, which will be discussed in detail shortly.

${ }^{11}$ The unfair prejudice petition in the Companies Act 1985, superseding the little-used and stringent oppression action in the previous Companies Act 1948.

${ }^{12}$ The rise in the supervision of financial market intermediaries and activity under the Financial Services Act 1986 which established the Securities and Investments Board.
} 
interests were also promoted via more prescriptive corporate governance standards. ${ }^{13}$ Securities regulation took off as part of European legal harmonisation in the $2000 \mathrm{~s},{ }^{14}$ further advancing corporate transparency and anti-market abuse as measures of investor protection.

In mapping out the landscape for minority shareholder protection in the UK, Chiu ${ }^{15}$ has argued that minority shareholder remedies based on company law rights, such as the derivative action and unfair prejudice petition, are framed in such a way that can rarely be used by minority shareholders in the capital markets. ${ }^{16}$ More substantive minority shareholder protection is increasingly found in securities regulation. However, corporate transparency promoted by securities regulation only supports minority shareholder protection in the sense of informing shareholder trading and exit strategies. In the UK, it does not adequately offer significant opportunities for investor power to be exercised through private securities litigation. Hence, minority protection based on securities litigation can largely been seen as 'law in the books' but not in action due to procedural barriers in civil justice and the collective action problem. ${ }^{17}$

However, as part of a 'soft law' component of securities regulation, the UK Listing Rules have, since the 1990s, maintained a requirement that listed companies in the highest listing category of the LSE should comply with the provisions of the prevailing Code of Corporate Governance or else explain any deviations. The Code describes best practices in corporate governance - particularly in relation to the structure, composition and functioning of the board of directors and its committees. Adherence to the Code is intended to provide minority investors with an adequate ex ante level of protection through the mechanism of an effective board which takes account of the interests of all shareholders (including minority interests) in the direction of the company. The current UK Code has evolved since

\footnotetext{
${ }^{13}$ Cadbury Report, below.

${ }^{14}$ See Financial Services: Implementing the Framework for Financial Markets- Action Plan (1998) COM (1999)232; Final Report of the Committee of Wise Men on European Securities Markets (Lamfalussy Report) (2001); Eilis V Ferran, Building an EU Securities Market (Cambridge: Cambridge University Press 2004).

${ }^{15}$ Iris H-Y Chiu, 'A Confidence Trick: Ex Ante versus Ex Post Frameworks in Minority Investor Protection in the UK' (2014) 11 European Company Law 6.

${ }^{16}$ This is because there are procedural barriers to overcome in the derivative action, such as showing a prima facie case and the court needs to be convinced at the preliminary stage of approving the action that the action would be in the interests of the company's long-term success. This is difficult as litigation generally has negative effects on share price and could be disruptive for the company. On the unfair prejudice action, courts have interpreted this action to be available largely to shareholders in closely knit private companies due to equitable and justice issues. Where companies are widely held and shareholders do not have significant personal stakes in their relations with each other, the availability of the action is highly limited to corporate constitutional issues only. See O'Neill v Phillips [1999] UKHL 24.

${ }^{17}$ Above.
} 
the first Cadbury Code of Corporate Governance and is often seen as a leading standard ${ }^{18}$ in the advancement of the 'soft law' approach to corporate governance. Premium-listed companies $^{19}$ are subject to it on a comply-or-explain basis, meaning that companies are urged to comply, but are free to provide explanations in their annual reports if they deviate from the Code's provisions (although they must always comply with its principles).

The Corporate Governance Code has a quasi-mandatory character as part of the securities regulation framework. The obligation to comply or explain means that the Code is not contrary to popular perceptions - an entirely voluntary or self-regulatory mechanism; Premium-listed companies have no choice but to engage with the Code. Nonetheless, it reflects an investment culture that is 'negotiated' ${ }^{20}$ - bottom-up and dialogic in nature. The Code maintains a delicate balance in soft law between increasingly prescriptive corporate governance standards preferred by the buy-side $e^{21}$ and support for flexibility in governance policies $^{22}$ favoured by the issuer community.

Minority shareholders in the UK have come to regard shareholder engagement on the basis of the Code and substantial compliance with the Code's main provisions as a key form of minority shareholder protection. ${ }^{23}$ In other words, in the absence of 'law in action' in the regimes of company law and private securities litigation, there is a marked trend in favour of corporate governance standards and company-shareholder engagement ${ }^{24}$ as the key means of realising minority shareholder protection in UK listed markets. Minority shareholders

\footnotetext{
${ }^{18}$ Financial Reporting Council, Comply or Explain: $20^{\text {th }}$ Anniversary of the UK Corporate Governance Code (London, 2012).

${ }^{19}$ When admitted to the Main Market of the London Stock Exchange, issuers may choose between a Premium (formerly Primary) Listing, a Standard (formerly Secondary) Listing or an Admission via the High Growth Segment.

${ }^{20}$ Alan Dignam, 'Exporting Corporate Governance: UK Regulatory Systems in a Global Economy' (2000) Company Lawyer 70.

${ }^{21}$ Buy-side preferences for increased prescription have strengthened in the wake of corporate scandals dating from the 1990s, and more recently played out in the global financial crisis. Buy-side support for more prescriptive governance obligations was a feature of the responses to the public consultations on the Enhanced Listing Regime, and buy-side preferences may be particularly influential in the design of minority shareholder protection in the UK, see FCA, Feedback on CP12/25: Enhancing the Effectiveness of the Listing Regime and Further Consultation (Nov 2013) at 16, 17, 19 and 20.

${ }^{22}$ Financial Reporting Council, 'Comply or Explain: 20th Anniversary of the UK Corporate Governance Code. Essays.' 2012.

${ }^{23}$ Marc Moore, 'Whispering Sweet Nothings: The Limitations of Informal Conformance in UK Corporate Governance' (2009) 9 Journal of Corporate Law Studies 77-120.

${ }^{24}$ UK Corporate Governance Code 2012, UK Stewardship Code 2012.
} 
therefore view the exercise of 'voice' as an important means of protection, ${ }^{25}$ although the institutional community has tended to rely more on issuer compliance with the Code than engagement. ${ }^{26}$ There is a danger that minority shareholders find superficial comfort in a form of compliance that is based on box-ticking.

Minority exercise of voice may be through voting at General Meetings, levels of which have improved over the years ${ }^{27}$ or through informal engagement supported by the UK Stewardship Code, introduced in $2010 .{ }^{28}$ In practice, shareholder engagement is motivated by a range of different interests and minority shareholders do not consistently avail themselves of it. ${ }^{29}$ However, the framework for engagement can be seen as viable and attractive to investors. A key issue underpinning the introduction of the Enhanced Listing Regime was uncertainty about whether the soft law nature of the UK Corporate Governance Code was sufficient to protect minority shareholder interests in the unfamiliar context of blockholder-controlled companies.

\section{The Enhanced Listing Regime and Minority Shareholder Protection}

The LSE has historically attracted listings from all over the world, particularly in the period since the enactment of the Sarbanes-Oxley Act 2002, which reduced the attractiveness of US capital markets to some foreign issuers. ${ }^{30}$ In April 2010, the UK Listing Authority (which was the Financial Services Authority but is now the Financial Conduct Authority) introduced

\footnotetext{
${ }^{25}$ Albert O. Hirschman, 'Exit, Voice, and Loyalty: Responses to Decline in Firms, Organizations, and States. Vol. 25. Harvard University Press, 1970.

${ }^{26}$ Marc Moore, 'Whispering Sweet Nothings: The Limitations of Informal Conformance in UK Corporate Governance' (2009) 9 Journal of Corporate Law Studies 77-120.

${ }^{27}$ Paul Hewitt, 'The Exercise of Shareholder Rights' (2011) at http://dx.doi.org/10.1787/5kg54d0l1lvf-en.

${ }^{28}$ which provides a set of best practices for institutional shareholder engagement. Recommended in David Walker, Review of Corporate Governance in UK Banks and Financial Institutions (Final, 26 Nov 2009) at http://www.hm-treasury.gov.uk/walker review information.htm. See Iris H-Y Chiu, 'Turning Institutional Investors into "Stewards" - Exploring the Meaning and Objectives of "Stewardship"' (2013) Current Legal Problems 1 for an analysis of the Code, and some initial evaluation of the Code in Simon CY Wong, "Why Stewardship is Proving Elusive to Institutional shareholders" (2010) Butterworths Journal of Banking and Financial Law 406.

${ }^{29}$ Financial Reporting Council, Developments in Corporate Governance 2013 The impact and implementation of the UK Corporate Governance and Stewardship Codes (Dec 2013) at 21ff.

${ }^{30}$ Peter Hostak, Thomas Lys, Yong George Yang, and Emre Carr, 'An Examination of the Impact of the Sarbanes-Oxley Act on the Attractiveness of U.S. Capital Markets For Foreign Firms', (2013) 18 Review of Accounting Studies 522-559.
} 
the Premium/Standard listing categories ${ }^{31}$ in order to bind most of the LSE's listed companies to the UK's brand of corporate governance standards.

Following the introduction of the new regime, most of the LSE's Primary listed companies shifted to the Premium category where they are required to comply with the provisions of the UK Corporate Governance Code or else explain any deviations. ${ }^{32}$ EU passported listed companies are no longer allowed to merely adhere to harmonised EU legislation which does not impose such a requirement. Non-EU companies listed on the London Stock Exchange (LSE) are able to become Premium listed companies and are subject to the corporate governance standards in the Code. This is potentially appealing to global companies as the branding of the Premium listing allows them to signal their adherence to the most stringent standards of UK corporate governance.

As of 30 April 2014, the total number of companies listed on the LSE was $1,304^{33}$ with about a third (427) of companies incorporated outside of the UK. The development of corporate governance standards in the UK has occurred in the context of a dispersed ownership model. However, foreign companies that are Premium listed on the LSE are also required to adhere to the UK standards even if they have a different ownership structure i.e. a concentrated ownership model.

A number of large foreign Premium listed companies have recently been embroiled in governance controversies which arguably reflect the less desirable features of concentrated ownership. These widely-publicised cases have created new uncertainties for UK investors and regulators, both of which have traditionally focused on agency type problems arising in a dispersed ownership system. ${ }^{34}$ This has prompted a key question about the functioning of the UK listing regime. Is the widely-praised UK corporate governance framework which has been developed to deal with principal-agent type governance problems - and applied by means of soft law - also adequate for dealing with issues arising from the principal-principal conflicts that can emerge in firms with concentrated ownership $?^{35}$ We now describe the three main cases that have thrown this hypothesis into doubt.

\footnotetext{
${ }^{31}$ FSA, Listing Regime Review (Feb 2010) and Listing Regime Review: A Consultation Paper (November 2009).

${ }^{32}$ FCA Handbook, LR 9.8.6.

${ }^{33}$ http://www.londonstockexchange.com/statistics/companies-and-issuers/companies-and-issuers.htm for statistics as of 28 Feb 2014 (accessed 17 March 2014).

${ }^{34}$ e.g. relating to shareholder and board oversight of the CEO and senior management team.

${ }^{35}$ Some studies have observed that corporate governance principles designed to deal with the agency problem between managers and shareholders are not necessarily appropriate to overcome the issues that arise with a blockholder corporate governance structure, see Victor Zitian Chen, Jing Li and Daniel M Shapiro, 'Are OECDprescribed “Good Corporate Governance Practices” Really Good in an Emerging Economy?' (2011) 28 Asia Pacific Journal of Management 115.
} 
In 2011, Bumi plc, which evolved from a Jersey incorporated investment vehicle (Valar plc) founded by Nathaniel Rothschild was floated on the LSE. Valar Plc was originally a cash shell, attracting investment from institutional investors largely on the basis of the reputation of Rothschild and his business partners, and only afterwards became engaged in mining activities after Rothschild decided to invest the company's assets in two Indonesian mining companies. Bumi plc was block-held, featuring two Indonesian companies that in combination owned the majority stake. Rothschild, who owned a minority stake of about $7 \%$, then fell out with his co-shareholders, the influential Bakrie family of Indonesia, over allegations of misappropriation of moneys by the latter of up to $£ 1 b n$ and financial statement misrepresentations. ${ }^{36}$

The Bakrie family then tried to remove Rothschild from the Board and dilute his stake, but Rothschild alleged abuse of minority rights and unsuccessfully attempted a coup to seize control of the Board. Ultimately, in early 2013, in the face of highly critical scrutiny from the UK media and a plummeting share price (to around one-fifth of its IPO valuation), the Bakrie family agreed to sell their stake to an Indonesian businessman (Samin Tan) who remained on the Board and as a long term shareholder. The split from the Bakrie family entailed the renaming of Bumi plc to Asia Mineral Resources ${ }^{37}$, although its main asset remained a coal miner, the fifth largest company in Indonesia.

Eurasian Natural Resources Corporation (ENRC) ${ }^{38}$ was another blockholder-controlled firm entangled in governance problems. It was founded in Kazakhstan in 1994 and co-owned by three oligarchs (Alexander Mashkevitch, Patokh Chodiev and Alijan Ibragimov), a Kazakh company (Kazakhmys) and the Kazakh state. ENRC focused on natural resources mining including iron ore, aluminium, coal, copper and cobalt. ENRC was headquartered in London and subsequently listed on the LSE in 2006. Amidst boardroom rows surrounding the controversial purchase of a mining concession in the Democratic Republic of Congo, two of its independent directors, Sir Richard Sykes and Ken Olisa, were voted off the Board by the majority shareholders at the 2011 AGM. Two further non-executive directors stepped down at the same time. Following an inconclusive investigation by an external law firm, the Serious Fraud Office in the UK commenced investigations into allegations of corruption, fraud and bribery at ENRC in April 2013. Not surprisingly, each of these developments was associated with significant declines in the share price.

\footnotetext{
${ }^{36}$ See for example, 'Nat Rothschild set for showdown with Samin Tan as Bumi chairman raises stake in beleaguered business', The Independent (11 July 2013).

37 'Curtain comes down on Bumi after shareholders vote for split', The Telegraph (17 Dec 2013).

38 'ENRC 'should have set off alarm bells', Financial Times (22 November 2013).
} 
In the face of unrelenting public exposure and criticism ${ }^{39}$, ENRC decided to take the company private and proposed to buy out the $18 \%$ free float of shares on the LSE. The buyout offer was criticised by independent board members to be at a significant undervalue. However in August 2013, most of the minority shareholders had accepted the offer which was worth only about $45 \%$ of the original float price. The company then delisted from the LSE on 28 October 2013.

Another unfortunate episode unfolded in early 2014 at Essar Energy, ${ }^{40}$ an Indian resources company listed on the LSE in April 2010 . The company was $78 \%$ controlled by an investment vehicle owned by Indian billionaires, the Ruia family. Essar began to suffer major losses for a variety of reasons, including a high debt burden and setbacks in energy permit negotiations with the Indian Government. ${ }^{41}$ The share price lost almost $75 \%$ of its IPO valuation, at which point the blockholder decided to take the company private. The minority shareholders were made a buyout offer at the prevailing low market valuation. Both the minority shareholders, which included UK institutions and insurance companies, and a special committee of Essar Energy's own independent directors criticised the opportunistic buyout offer and appealed to the blockholder to respect the interests of minority shareholders as well as those of the majority. However, in the face of an uncompromising attitude from the blockholder, both saw little choice other than to accept in view of imminent delisting. ${ }^{42}$

The experiences of Bumi, ENRC and Essar Energy highlighted to investors that minority expropriation ${ }^{43}$ and lack of external accountability are side effects that may be associated with the concentrated ownership model. The sheer unfamiliarity of the UK equity market with blockholder-controlled entities also added to a widespread public perception that concentrated ownership was synonymous with 'weak' governance. However, it is by no means obvious from empirical studies that concentrated ownership , per se, is systematically associated with inferior corporate performance. ${ }^{44}$ Many commentators have convincingly argued the blockholder model may, in the right institutional context, promote

\footnotetext{
39 One of the ejected directors, Ken Olisa, famously described the culture at ENRC as "more Soviet than City". 'ENRC “Soviet-style" control accusation denied', Financial Times (14 June 2011).

${ }^{40}$ See ‘Essar Energy Bid Turns Hostile’, Financial Times (14 March 2014).

41 'Reversal of fortunes for India takes toll on Essar Energy', Financial Times (18 February 2014)

42 'Essar Energy panel backs Ruia family's take-private offer', Financial Times (13 May 2014).

${ }^{43}$ For example Brown v. British Abrasive Wheel Co [1919] 1 Ch 290; Dafen Tinplate Co Ltd. v Llanelli Steel Co [1920] 2 Ch 124.

${ }^{44}$ Steen Thomsen and Torben Pedersen, 'Ownership Structure and Economic Performance in the Largest European Companies’ (2000) 21 Strat. Mgmt. J. 689-705.
} 
positive governance values such as better agency monitoring, ${ }^{45}$ long-termism and shielding from capital market pressures that may allow companies to focus on research, investment and long-term growth and sustainability. ${ }^{46}$

Nonetheless, the UK Listing Authority, in the light of adverse media coverage and pressure from institutional investors, felt compelled to respond to the negative episodes with the introduction of a new set of listing rules ${ }^{47}$ to boost minority shareholder protection in blockholder-controlled companies. The resulting Enhanced Listing Regime seeks to protect minority shareholders by 'ensuring the voice of minority shareholders is heard when the behaviour of a controlling shareholder is not appropriate'. ${ }^{48}$ Following two rounds of consultation, ${ }^{49}$ the reforms came into force on 16 May $2014 .{ }^{50}$

We are of the view that the Enhanced Listing Regime is in spirit a defensive measure to protect the reputational brand of the UK listing regime as perceived by institutional investors. It may also reflect an underlying fear that the UK Corporate Governance Code is not necessarily well positioned to deal with blockholder-related governance issues. Its model of voice facilitation has been developed in the context of dispersed ownership where it seeks to promote dialogue and negotiation between companies and external shareholders. However, in a blockholder-controlled company, major shareholders are in a position to directly impose their governance preferences. Although any non-compliance with the Code must still be explained to the market, there is much less scope to force such companies to engage with those minority shareholders that are not supportive of the chosen governance framework. The Code is hence potentially a much less effective ex ante minority protection mechanism in blockholder-controlled companies.

We do not perceive, however, that the episodes discussed above have significantly tarnished the more general brand of the UK Corporate Governance Code. The Enhanced Listing Regime is framed separately from the Code and focused on a relatively small

\footnotetext{
${ }^{45}$ Alex Edmans, 'Blockholder Trading, Market Efficiency, and Managerial Myopia' (2009) 64(9) Journal of Finance 2481.

${ }^{46}$ Marc Moore and Edward Walker-Arnott, 'A Fresh Look at Stock Market Short-Termism' (2014) 41(4) Journal of Law and Society (forthcoming).

${ }^{47}$ Financial Conduct Authority, Enhancing the Effectiveness of the Listing Regime :A Consultation Paper (Nov 2012) and Enhancing the Effectiveness of the Listing Regime and Further Consultation (November 2013).

${ }^{48}$ Financial Conduct Authority, Enhancing the Effectiveness of the Listing Regime and Further Consultation (November 2013) at para 2.6.1.

${ }^{49}$ Financial Services Authority, Enhancing the Effectiveness of the Listing Regime and Feedback on CP12/2 (Oct 2012); Financial Conduct Authority, Enhancing the Effectiveness of the Listing Regime and Further Consultation (November 2013).

${ }^{50}$ FCA, 'Response to CP13/15 - Enhancing the Effectiveness of the Listing Regime' (16 May 2014).
} 
segment of the listed market. This demarcated approach permits regulators to avoid confronting the wider question of whether soft law is adequate for promoting good governance across the market as a whole. Nonetheless, we speculate that increased prescription in corporate governance is a developing trend which is already making a major impact on financial sector governance ${ }^{51}$. Over time, the Enhanced Listing Regime may come to be seen as part of a wider trend towards more binding and prescriptive corporate governance standards in UK listed equity. ${ }^{52}$

We nevertheless raise doubts as to whether the Enhanced Listing Regime adequately deals with some specific governance issues that have emerged in blockholder-controlled issuers. Furthermore, we are concerned that this new regime may be underpinned by a lack of insight into the more positive aspects of blockholder ownership revealed in various other successful economies. ${ }^{53}$

The first key component of the Enhanced Listing Regime is that, if a Premium-listed company has a controlling shareholder, ${ }^{54}$ the controlling shareholder must enter into a mandatory agreement ${ }^{55}$ with the company. This agreement is intended to regulate the blockholder's influence over the company, ensure that the company's constitution does not undermine the position of minority shareholders and preserves the 'independence' of the business. The aim is to limit the extent of private benefit that can be extracted by controlling shareholders as well as mitigate the lack of accountability to minority shareholders.

Business 'independence' is defined in broad terms, meaning that the company is not overly reliant on conducting business with the controlling shareholder or on access to the controlling shareholder for financing. The business must have strategic control over its assets, business strategy and ability to earn revenue. Independence from the controlling shareholder means that all commercial transactions and arrangements conducted with the controlling shareholder have to be at arm's length and on normal commercial terms. The

\footnotetext{
${ }^{51}$ Roger M. Barker, 'The New Governance of UK Finance: Implementing the Walker Review.' Butterworths Journal of International Banking and Financial Law, May 2010. See also Article 88 of Directive 2013/36/EU on access to the activity of credit institutions and the prudential supervision of credit institutions and investment firms (CRD IV).

52 The nature of corporate governance standards reflects the strength of minority shareholder protection regimes and the issue of whether such standards should be regarded as 'law' or 'soft law' could be of great practical importance.

${ }^{53}$ e.g. in continental Europe and many fast growing Asian markets.

${ }^{54}$ defined as a shareholder with control of at least $30 \%$ of the voting shares.

${ }^{55}$ Listing Rules 6.1.4ff. It is not necessary that every controlling shareholder enters into a separate agreement.
} 
controlling shareholder must also agree to not to take any step that would circumvent the Listing Rules.

If a Premium-listed company fails to put in place a mandatory agreement, or fails to comply with the independence terms, or if an independent director on the Board is of the view that the agreement is not complied with, then minority independent shareholders are given extra monitoring powers to veto all related-party transactions. ${ }^{56}$ However, the threat of delisting is not used as an enforcement mechanism - otherwise minority independent shareholders would be further punished by being cut off from any ability to sell their equity stake.

A second key aspect of the Enhanced Listing Regime introduces a re-ordering of voting rights under certain circumstances. This aims to give more weight to minority shareholders' voice than would ordinarily be the case in the General Meeting. In particular, independent minority shareholders are provided with additional voice when appointing independent directors or when a cancellation of the Premium listing is proposed. Their approval by majority is sought as a class instead of being subsumed under the General Meeting, although in the case of electing independent directors, a protest vote of independent shareholders can only temporarily delay the majority decision for a period of 90 days.

An earlier proposal to compel boards of blockholder-controlled companies to appoint a majority of independent directors was ultimately dropped from the final rules. The Listing Authority was persuaded to refrain from over-prescription on boardroom composition at the behest of the UK issuer community, although there was significant buy-side support for the introduction of a mandatory requirement for a majority of independent directors. ${ }^{57} \mathrm{We}$ now proceed to a more detailed analysis of the key measures.

\section{Re-ordering Voting Powers in Favour of the Minority and Consistency with Company Law}

As described above, the Enhanced Listing Regime requires approval of minority independent shareholders voting as a class in two situations: election of independent directors and where a cancellation of the Premium listing is sought.

The former is particularly important to minority shareholders. Independent directors are potentially well-placed to address some of the main governance problems that have arisen in blockholder-controlled issuers, such as lack of external transparency, abuse of relatedparty transactions, weaknesses in internal control systems and non-compliance with anticorruption and bribery legislation. The privileged position of independent directors as company 'insiders', with influence over decision-making, can potentially act as a significant

\footnotetext{
${ }^{56}$ with no minimum size threshold.

${ }^{57}$ Financial Conduct Authority, Enhancing the Effectiveness of the Listing Regime and Further Consultation (November 2013) at para 3.19.
} 
check on the blockholder's power. Minority shareholders therefore have a strong interest in securing the appointment of robust and capable independent directors to the board.

Can such re-ordering of voting rights be supported in company law? The company law framework regulates the exercise of majority power in general meetings subject to the standard of 'reasonable hypothetical shareholder acting bona fides in the interest of the company as a whole' ${ }^{58}$ Case law jurisprudence recognises that where a majority stake exists, the exercise of such powers could be adverse to the minority's interests, particularly in the context of constitutional amendments. However, courts have refrained from interfering excessively with voting powers exercised at general meetings. ${ }^{59}$ In Australia, courts can prevent the successful exercise of majority power if unfairly oppressive consequences result for minority shareholders. ${ }^{60}$ Such position has not been followed in the UK. ${ }^{61}$ The policy position in the UK, at least before the passage of the Companies Act 2006, seemed to be reluctant to upset the private proprietary rights attached to shareholdings.

It could be argued that UK courts have largely upheld the power of the majority vote because there are specific minority shareholder remedies in company law, ${ }^{62}$ which render it inappropriate for courts to achieve minority protection through a tampering with the exercise of voting powers. But the unfair prejudice petition for minority shareholders ${ }^{63}$ is rarely utilised in the context of listed companies as judicial interpretation of 'unfair prejudice' has made its application much more pertinent to closely-held private companies. ${ }^{64}$ Further, derivative litigation has been rare ${ }^{65}$ and is unlikely to be easily utilised given the procedural barriers in the legal framework. ${ }^{66}$

\footnotetext{
${ }^{58}$ Greenhalgh v Ardene Cinemas Ltd (CA) [1951] Ch 286; Citco Banking Corp v Pusser's Ltd [2007] BCC 205.

${ }^{59}$ Citco Banking Corp v Pusser's Ltd [2007] BCC 205.

${ }^{60}$ Gambotto v WCP Ltd. (1995) 127 ALR 417.

${ }^{61}$ The DTI Final Report rejected Gambotto and endorsed Greenhalgh: see Chapter 7, paras.7.52-7.61.

${ }^{62}$ S260ff, Companies Act 2006, on the derivative action and s994 on the unfair prejudice petition.

${ }^{63}$ S994, Companies Act 2006.

${ }^{64}$ See the jurisprudence on 'quasi-partnerships', O'Neill v Phillips [1999] BCC 600; Ebrahimi v Westbourne Galleries Ltd and others [1972] 2 All ER 491; Boughtwood v Oak [2010] EWCA Civ 23; Croly v Good [2010] EWHC 1; Maidment v Attwood [2012]EWCA 998; Moxon v Litchfield \& Ors [2013] EWHC 3957.

${ }^{65}$ John Armour, Bernard Black, Brian Cheffins and Richard Nolan, 'Private Enforcement of Corporate Law: An Empirical Comparison of the UK and US' (2009) 6 Journal of Empirical Legal Studies 687.

${ }^{66}$ See critical reflections by Arad Reisberg, 'Derivative Claims under the Companies Act 2006: Much Ado About Nothing?' in J Armour and J Payne (eds), Rationality in Company Law: Essays in Honour of DD Prentice (Oxford: Hart Publishing, 2009) at 17.
} 
Given that one of the most attractive features in UK minority shareholder protection is respect for minority shareholder voice, the re-ordering of voting rights in the Enhanced Listing Regime can be viewed as broadly consistent with the facilitative nature of company law. Although the Regime prima facie distorts the balance of voting power in the general meeting, the over-weighting of minority voting rights in specified circumstances is arguably necessary to provide them with the capacity to exercise their voice and participatory rights under company law. ${ }^{67}$

Further, legislative tinkering with voting powers is not new. Section 239 of the Companies Act 2006 provides that ratification of directors' breaches of duty can be achieved by a majority vote in the general meeting, provided that interested shareholders' votes are ignored. This form of legislative intrusion under-weights the voting power of the relevant shareholder but preserves the integrity of the ratification process. Such re-ordering of voting rights also achieves the internalisation of companies' management affairs and minimises the externalisation of irregularities onto public arenas such as courts. One could view the Enhanced Listing Regime in a similar way, i.e. providing a facilitative framework for minority voice to be heard.

Mukwiri and Siems ${ }^{68}$ have argued for caution in protecting minority shareholders by increases in voting power, for fear of the adverse incentives such changes in power dynamics may introduce for management bodies. They advocate protection of minority shareholders without resorting to increases in voting power, such as through greater transparency.

For example, a 'middle way' of enhancing shareholder voice without tinkering with voting powers could be achieved by empowering minority shareholders to request more information. Information request rights could further be supported by a right to obtain an injunction against proceeding with a course of action still subject to explanation to minority shareholders, similar to the kind of injunction a shareholder may obtain to restrain directors from constitutional breaches. ${ }^{69}$ However, 'middle way' rights designed to enhance minority voice may be regarded as weak because abusive behaviour may not be prevented although it could subsequently be discovered. Besides, the ethos of facilitating shareholder voice would support ex ante rights such as the re-ordering of voting rights instead of relying on ex post remedies.

\footnotetext{
${ }^{67}$ Art 4, Model Articles for Private Companies Limited by Shares, Model Articles for Public Companies Limited by Shares; Quin \& Axtens v Salmon [1909] AC 442. Also see power to remove directors, Section 168, Companies Act 2006; power to amend the constitution, section 21, Companies Act 2006.

68 Jonathan Mukwiri and Matthias Siems, 'The Financial Crisis: A Reason to Improve Shareholder Protection in the EU?' (2014) 41 Journal of Law and Society 51.

69 under section 40 of the Companies Act 2006.
} 
In relation to enhancing minority voting power where a cancellation of the Premium listing is concerned, we are of the view that the Enhanced Listing Regime does not adequately address the problem of disadvantageous minority buyouts. On the face of it, the new rules allow minority shareholders to block any proposal to cancel a Premium listing. Their approval needs to be sought as a class, and the general meeting must on the whole approve the cancellation by a special majority of $75 \%$. However, the majority vote of minority independent shareholders can be dispensed with in a takeover situation if another corporate entity succeeds in acquiring $80 \%$ of the voting power or more. ${ }^{70}$

This technique was utilised to de-list Essar Energy from the LSE in June $2014 .^{71}$ The controlling family already owned $78 \%$ of Essar Energy. The family used an unlisted corporate entity under their control ${ }^{72}$ to launch a hostile takeover for Essar Energy and acquire another 2\% from minority shareholders. At that point, the Board of Essar Energy - including its independent directors - conceded that the threshold had been passed for the controlling blockholders to delist and reluctantly recommended that remaining minority shareholders should accept the buyout offer.

Essar Energy's success in buying out the minority shareholders was also due in part to the low free float of the company's shares - at the time of its IPO, Essar obtained a waiver in respect of the normal minimum $25 \%$ free float requirement (on the basis that the market liquidity of the shares was sufficiently high). Although we agree that significantly raising the minimum free float requirement, an option mooted at consultation but rejected by the $\mathrm{FCA}^{73}$, would have been an undesirable way of protecting minority voice, regulators would be well advised to ensure that waivers from existing free float requirements are applied only sparingly in the future.

\section{Mandatory Agreement and Consistency with Corporate Governance Standards}

The Mandatory Relationship Agreement ${ }^{74}$ (MRA) required by the Enhanced Listing Regime is a measure that seeks to pre-commit controlling shareholders to the 'independence' of the business and the importance of minority voice. As a key minority fear lies in the risks of tunnelling and misappropriations by the controlling block-holder, it can be argued that the

\footnotetext{
${ }^{70}$ Once that has been achieved, no further approval/acceptances by independent shareholders are required to cancel the Premium listing and take the company private.

71 'Essar Energy panel backs Ruia family’s take-private offer’, Financial Times (13 May 2014).

${ }^{72}$ Essar Global Fund Limited.

${ }^{73}$ The minimum free float of $25 \%$ is consistent with the NYSE and SEHK studied in this article and higher than several other jurisdictions including Singapore Stock Exchange which requires only a minimum $10 \%$ free float.

${ }^{74}$ The terminology 'relationship agreement' has subsisted under the final consultation CP13/15, and has changed to 'mandatory agreement' in the final Policy Statement PS14/18.
} 
mandatory independence provisions in the MRA will keep related-party transactions and arrangements under check. The MRA is principally monitored by independent directors, whose signalling of non-compliance will trigger minority veto rights to related-party transactions, however small.

We raise several concerns with respect to this new measure. A first is that such independence provisions could ultimately limit the benefits that a controlling blockholder brings to the company albeit mitigating some of the risks.

Corporate governance standards in the UK have been developed with the primary objective of overseeing and controlling the undue personal agendas that corporate management may pursue. Hence the structures of independent directors, board committees and shareholder engagement have been institutionalised to monitor those in control. The MRA is introduced within the same ethos in relation to preserving the independence of the business, in this case with respect to controlling shareholders rather than management.

However, the nature of the blockholder's influence over a company is arguably different from that of a CEO or top manager. The blockholder's stake in a company will generally comprise of a larger personal financial commitment, a firm-specific stake in terms of skills and innovation and possibly an emotional stake based on founding, family or other personal attachment. These factors may play a powerful role in aligning the blockholder's motivation with the long-term success of the company. ${ }^{75}$ In contrast, the professional manager's stake is likely to be largely financial and more short-term. Academic literature points to the difficulties in designing executive remuneration to motivate towards long term performance. $^{76}$

The nature of the founding block-holder/controller's relationship to a company was emphasized by Ken Moelis in a recent high profile market listing. The Moelis IPO ${ }^{77}$ highlighted the founder shareholder's fears that minority activist shareholders such as hedge funds could divert the attention of the company for short termist purposes and disrupt the blockholder's long term vision.

The MRA's framework for preserving the independence of the business may introduce disincentives for blockholder commitment to the company. It is legitimate to ask if the MRA is a necessary measure in order to resolve welfare-destroying conflicts between

\footnotetext{
${ }^{75}$ Marc Moore and Edward Walker-Arnott, 'A Fresh Look at Stock Market Short-Termism' (2014) 41(4) Journal of Law and Society (forthcoming).

${ }^{76}$ Lucian Bebchuk and Jesse Fried, Pay without Performance: The Unfulfilled Promise of Executive Pay (Mass: Harvard University Press 2006).

77 'Ken Moelis Defends Dual-class Structure’, Financial Times (16 April 2014).
} 
shareholders or if it is merely acceding to the special interests of institutional investors with negative implications for the success of the company as a whole.

A second possible concern is that the MRA is an agreement entered into between controlling shareholders (defined widely and including associates of controlling shareholders) and the company. Minority shareholders are not privy to those agreements. The MRA is neither strictly speaking a constitutional document as it does not bind all members of the company, neither is it a private shareholders' agreement. There is a need to critically analyse the nature of the MRA and its implications for minority shareholder protection.

As minority independent shareholders are not privy to the MRA, they do not have a right to enforce it. In fact there would appear to represent a lacuna in enforcement as the company in such a scenario would be in the hands of the blockholder. Further, minority shareholders may not be able to take derivative actions against the blockholder as a breach of the MRA may not be regarded as a breach of directors' duties. ${ }^{78}$

The Enhanced Listing Regime addresses these problems by increasing monitoring rights for minority shareholders in blockholder-controlled companies. It empowers them to veto any related-party transactions in the event of a breach. Such a breach would invariably be determined by independent directors, as the opinion of an independent director, even if contrary to the Board, would trigger the minority veto rights. Hence, it is arguable that the agreement between the controlling blockholder and company would in fact be 'enforced' by minority independent shareholders on behalf of the company. This puts minority independent shareholders in a representative capacity for the company.

One wonders if acting in a representative capacity for the company may trigger fiduciary duties owed to the company in the specific context of preserving the independence of the business. Can the preservation of the independence of the business be equivalent to the wider duty under section 172 to promote the long term success of the company for the benefit of all members as a whole? Could the actions of the minority independent shareholders be subject to judicial scrutiny and claims by the blockholders? It may be argued that where minority veto rights are triggered under the MRA, they are not exercised as a matter of minority voice but as representative voice in the company's interests. It is important to consider the implications for minority shareholders in terms of obligations if such rights are triggered.

Further, where independent directors determine a breach, there seems to be no further option for internal remediation. Minority veto rights are triggered right away. This would accord with the above observations that minority independent shareholders are acting in a

\footnotetext{
${ }^{78}$ Not under s171 if the MRA is not regarded as a constitutional document, and such breach need not be a breach of s172 either. There may be scope for arguing that the breach could fall within s175, as a breach of independence provisions may involve some conflict of interest.
} 
representative capacity, as required by the Enhanced Listing Regime, to preserve the independence of the business, and not in a personal capacity. Could a non-severe breach of the independence requirement be dealt with by ratification by minority independent shareholders instead? This would minimise the polarisation of positions in the general meeting and would facilitate dialogue. Structuring the MRA in such a way as to leave out minority shareholders as party may not be optimal and conducive to realising minority voice.

If minority shareholders are included in the MRA, then the MRA would likely become a constitutional document, falling within the definition of an agreement under section 29(d) of the Companies Act, arguably forming part of the company's constitution. Constitutional status would boost the rights and voice of minority independent shareholders as enforcement of the MRA could be carried out as personal rights ${ }^{79}$ or under the unfair prejudice petition. If so, it is possible to view the MRA as providing superior protection for minority shareholders where there is a controlling blockholder as compared to companies without a controlling blockholder. The Listing Rules would be providing safeguards in 'business independence' for minority shareholders in a block-held company, while minority shareholders facing other agency problems in widely-held companies are not provided with specific protection in terms of business conduct. Such constitutional status could boost the rights of minority independent shareholders to the point of over-correction.

The MRA's ambivalent nature may reflect its experimental and tentative position on special minority protection in block-held companies. It is a suis generis document that neither falls within the ambit of the company's constitution nor the contractual framework relating to shareholders' agreements (which could make the Listing Authority seem as if a framework has been put in place a framework to facilitate direct showdowns between controlling blockholders and minority independent shareholders). So we remain uncertain if minority protection is the exercise of a personal right or a representative right, the former being a more powerful tool whether it is constitutionally or contractually based. The latter interpretation may result in more burdens being imposed on minority independent shareholders. The uncertainties surrounding the obligations of independent directors and minority independent shareholders in enforcing the MRA could result in the cosmetic implementation of the MRA and a lack of enforcement.

A final concern is that the introduction of the MRA may generate the perception that the UK views blockholder-controlled companies negatively and this could make the LSE less attractive to international issuers. In March 2014, Jardine Lloyd Thompson Group (JLT) became the first Premium listed company to seek the Listing Authority's permission to downgrade to a Standard Listing in anticipation of avoiding the Enhanced Listing Regime. ${ }^{80}$ JLT is block-held by 5 companies controlled and owned largely by the Jardine family based in

\footnotetext{
${ }^{79}$ Section 33, Companies Act 2006.

80 'Jardines seeks to downgrade Premium London listing’, Financial Times (10 March 2014).
} 
Hong Kong, and has always had a history of insisting upon insider control and resisting compliance with best practices in corporate governance such as having independent directors on the Board. The Jardine Group is however well-known for taking a long term view over a range of carefully selected diversified businesses and has delivered consistent returns to minority investors. ${ }^{81}$

The JLT move can be viewed as suis generis. The Jardine Group has always jealously guarded its insider control, to the extent that it delisted 4 of its companies from the Hong Kong Stock Exchange in 1994 and relisted in Singapore due to a breakdown in its negotiations with the Securities and Futures Commission, to be exempt from the takeover regime in Hong Kong. ${ }^{82}$ It remains to be seen whether JLT's actions are representative of wider market sentiment.

\section{B. Minority Shareholder Protection in the US Listing Regime}

This Section will focus on the New York Stock Exchange (NYSE) as the premier listing destination in the US. Although the trio of the NYSE, Nasdaq and American Stock Exchange (AMEX) dominate the listed market in the US, the NYSE's historical significance and reputational standing makes it an apt comparative subject for the LSE. In 2012, it was recorded that $80 \%$ of Fortune 500 companies were NYSE-listed companies. ${ }^{83}$

Since Berle and Means's seminal study in the $1930 \mathrm{~s},{ }^{84}$ it has been widely assumed that most public companies in the US enjoy dispersed ownership. As a result, the key corporate governance questions are seen as revolving around the agency problems ${ }^{85}$ arising from the separation of ownership from control. However, Holderness observes that there is an overwhelming majority of listed firms in the US with a blockholder of at least $5 \%,{ }^{86}$ and Demott points out that $30 \%$ of Fortune 500 firms feature concentrated ownership, including

\footnotetext{
81 'Jardines still marches to its own beat', Financial Times (11 March 2014).

${ }^{82}$ Above. Also see Sie Ting Lau and Thomas H Mclnish, 'Trading Volume and Location of Trade: Evidence from Jardine Group Listings in Hong Kong and Singapore' (2003) 27 Journal of Banking and Finance 1411.

${ }^{83}$ http://www.nyse.com/events/1336386681007.html.

${ }^{84}$ Adolf A Berle and Gardiner C Means, The Modern Corporation and Private Property (Transaction Publishers, 1991 rep).

${ }^{85}$ M Jensen and W Meckling, "Theory of the Firm: Managerial Behavior, Agency Costs and Ownership Structure" (1976) 3 Journal of Financial Economics 305.

${ }^{86}$ Clifford G Holderness, 'The Myth of Diffuse Ownership in the United States' (2007) 22 Review of Financial Studies 1377.
} 
in US companies. ${ }^{87}$ Hence, block-held structures are common even in a jurisdiction that is often assumed to have attained widely-held democratic capitalism. ${ }^{88}$

However, if blockholding is defined as controlling at least a $20 \%$ voting stake, La Porta et $\mathrm{al}^{89}$ document that only $20 \%$ of large U.S. firms have blockholder-dominated ownership. It seems that although blockholders are common in the US economy, they tend to lack control rights. ${ }^{90}$ This leads Cheffins and Bank to conclude that "a separation between ownership and control remains an appropriate reference point for those seeking to come to terms with the historical development of U.S. corporate governance and current arrangements in public corporations". ${ }^{91}$

The main blockholders in US listed companies are founders, ${ }^{92}$ families ${ }^{93}$ and managers and employees. ${ }^{94}$ In particular, there is a growing trend for founders of Silicon Valley technology companies to retain control through a dual-class share structure in which voting rights exceed cash flow rights. Founder shareholders may be motivated to insist on such voting structures due to concerns about the potential risk of short-termism in widely-held corporations. For example, Google's founder shareholders Larry Page and Sergey Brin have retained significant control of $55.7 \%$ after the initial public offer of shares despite having

\footnotetext{
${ }^{87}$ Deborah DeMott, 'Guests at the Table?: Independent Directors in Family-Influenced Public Companies' (2007) at http://ssrn.com/abstract=1010732.
}

${ }^{88}$ For example, Henry Hansmann and Reinier Kraakman, 'The End of History for Corporate Law' (2000) 89 Georgetown Law Journal 439; which views were defended in a nuanced manner in Henry Hansmann, 'How Close is the End of History' (2005) at http://lesliecaton.com/wordpress/wp-content/uploads/2012/01/7Hansmann-FINAL.pdf; and in Hansmann and Kraakman, 'Reflections on the End of History for Corporate Law' (2011) at http://papers.ssrn.com/sol3/papers.cfm?abstract id=2095419, see also Coffee's views in John C Coffee Jnr, 'A Theory of Corporate Scandals: Why the U.S. and Europe Differ' (2005) at http://ssrn.com/abstract=694581.

89 La Porta, Rafael, Florencio Lopez-de-Silanes, and Andrei Shleifer, 'Corporate Ownership around the World' (1999) 54 Journal of Finance 471-517.

${ }^{90}$ Alex Edmans, 'Blockholder Trading, Market Efficiency, and Managerial Myopia' (2009) 64(9) Journal of Finance 2481 at 2483.

${ }^{91}$ Brian Cheffins and Steven Bank, 'Is Berle and Means Really a Myth?' (2009) 83 Business History Review 443474.

92 Paul A Gompers, Joy Ishii and Andrew Metrick, 'Extreme Governance: An Analysis of Dual-Class Firms in the United States' (2010) 23 Review of Financial Studies 1051.

93 Deborah Demott, 'Guests at the Table?: Independent Directors in Family-Influenced Public Companies' (2007) at http://ssrn.com/abstract=1010732.

${ }^{94}$ Clifford G Holderness, 'The Myth of Diffuse Ownership in the United States' (2007) 22 Review of Financial Studies 1377. 
only $15 \%$ of the cash flow rights. ${ }^{95}$ They cite their long-term perspective as rationale for supporting the issue of a class of non-voting shares, which controversially started trading in April $2014 .{ }^{96}$ Empirical research indicates that dual-class voting structures can reduce trust in companies and may be avoided by some investors. ${ }^{97}$ Gompers et al also find that listed companies with dual-class structures have by and large performed worse over the long term than those without a controlling shareholder. ${ }^{98}$ However, successful companies such as Berkshire Hathaway, News Corp, Google, Facebook, Amazon and a host of other internetbased companies such as LinkedIn, Zynga, Groupon and JD.com and Alibaba.com from China continue to attract investors who wish to share in the upside of successful companies led by talented founders (despite their apparently weak position as minority shareholders).

The legal frameworks for minority shareholder protection in the US are fragmented. Company law remains the province of state law and hence shareholder rights are determined by state law frameworks. ${ }^{99}$ Most academics ${ }^{100}$ have agreed that the state of

\footnotetext{
95 'John Plender: Google takes us back to Old Europe', Financial Times (9 May 2004).

96 'Google founders look to cement control with novel share split', Financial Times (2 April 2014).

${ }^{97}$ See earlier article by Vijay Jog and Allan L Riding, 'Price Effects of Dual-class Shares' (1986) Financial Analysts
} Journal 58.

98 Paul A Gompers, Joy Ishii and Andrew Metrick, 'Extreme Governance: An Analysis of Dual-Class Firms in the United States' (2010) 23 Review of Financial Studies 1051; 'The Cost of Control', The Economist (21 July 2011) at http://www.economist.com/node/18988938.

${ }^{99}$ Although not a constitutional divide, judicial opinion has upheld an 'internal affairs doctrine' that protects the province of state law in legislating company law matters such as corporate governance and the division of powers between corporate organs. See Edgar v. MITE Corp., 457 U.S. 624, 645 (1982); Robert B Thompson, 'Corporate Federalism in the Administrative State: The Sec's Discretion to Move the Line Between the State and Federal Realms of Corporate Governance' (2007) 82 Notre Dame Law Review 1143. Renee B Jones argues that the preserve of state law is a doctrine that can be challenged as there is not constitutional backing for it in the federal-state division of powers, see Renee B Jones, 'Does Federalism Matter? Its Perplexing Role in the Corporate Governance Debate’ (2007) 41 Wake Forest Law Review 879.

${ }^{100}$ Roberta Romano, The Genius of American Corporate Law (American Enterprise Institute 1993); Daniel R. Fischel, 'The "Race to the Bottom" Revisited: Reflections on Recent Developments' (1982) 76 Northwestern University Law Review 913; but its regulatory competition thesis towards race to the top has been doubted by commentators who point to other reasons why Delaware's pre-eminence persist, eg Kamar's imperfect competition thesis and Roe's political insights, see Ehud Kamar, 'A Regulatory Competition Theory of Indeterminacy in Corporate Law' (1998) Columbia Law Review 1908; Mark J Roe, 'Delaware's Competition' (2003) 117 Harvard Law Review 588. Further some commentators see the Delaware victory as a race to the bottom in terms of the pro-management stance of its corporate governance framework supported by judicial interpretation, see William L. Cary, 'Federalism and Corporate Law: Reflections Upon Delaware' (1974) 83 Yale Law Journal. 663; (1974); Lucian Arye Bebchuk \& Assaf Hamdani, 'Vigorous Race or Leisurely Walk: Reconsidering the Competition over Corporate Charters' (2002) 112 Yale L.J. 553; Jill E Fisch, 'The Peculiar Role of the Delaware Courts in the Competition for Corporate Charters' (2000) 68 University of Cincinnati Law Review 1061. 
Delaware has emerged as the winner for incorporations in the US. However, the forces of regulatory competition have shaped the Delaware company law regime into one that is promanagement in nature. ${ }^{101}$ Directors are largely protected by a business judgment rule ${ }^{102}$ that impedes judicial scrutiny of conduct that involves business judgment unless there is a breach of fiduciary duty. ${ }^{103}$ Shareholder derivative suits are rarely likely to succeed. ${ }^{104}$ Further, shareholder rights are rather limited. ${ }^{105}$ Bebchuk $^{106}$ points out that, compared to their UK counterparts, shareholders in Delaware-incorporated companies do not have the right to propose Charter amendments and are excluded from game-ending and corporate restructuring decisions. Further, Delaware upholds the right of management to defend vigorously against takeovers by means of poison pills so that the market for corporate control is muted in its disciplinary effect upon management. ${ }^{107}$

Despite this context, Gelter ${ }^{108}$ points out that shareholder primacy ${ }^{109}$ is paradoxically the dominant rhetoric in corporate law and management ideology. Shareholder primacy is

${ }^{101}$ Lucian Ayre Bebchuk and Allen Ferrell, 'On Takeover Law and Regulatory Competition' (2002) 57 Business Lawyer 1047.

${ }^{102}$ Aronson v. Lewis, 473 A.2d 805, 812 (1984); Franklin A Gevurtz, 'The Role of Corporate Law in Preventing a Financial Crisis: Some Reflections on In Re Citigroup Inc Shareholder Derivative Litigation' in PM Vasudev and Susan Watson (eds), Corporate Governance after the Financial Crisis (Cheltenham: Edward Elgar 2011), at p.163.

${ }^{103}$ For example, in Smith v. Van Gorkom, 488 A.2d 858 (Del. 1985), the directors were impeached for lack of due care as they did not adequately consideralternative tender offers in a takeover situation. The negative consequences of the decision for growth companies are documented in Yaniv Grinstein and Stefano Rossi, 'Good Monitoring, Bad Monitoring' (2014) at http://ssrn.com/abstract=1906326, and the authors also note that reforms have been introduced to mitigate the effect of the decision which could entail excessively risk averse behaviour for directors, inhibiting company innovation, investment and growth.

104 Martin Gelter, 'Why Do Shareholder Derivative Suits Remain Rare in Continental Europe?' (2012) 37 Brooklyn Journal of International Law 843 reports that shareholder derivative suits are often commenced but rarely succeed, and see Franklin A Gevurtz, 'The Role of Corporate Law in Preventing a Financial Crisis: Some Reflections on In Re Citigroup Inc Shareholder Derivative Litigation' in PM Vasudev and Susan Watson (eds), Corporate Governance after the Financial Crisis (Cheltenham: Edward Elgar 2011), at p.163.

${ }^{105}$ Christopher M Bruner, Corporate Governance in the Common Law World (Cambridge: Cambridge University Press, 2013).

${ }^{106}$ Lucian Ayre Bebchuk, 'The Case for Increasing Shareholder Power' (2005) 118 Harvard Law Review 833.

${ }^{107}$ Lucian Ayre Bebchuk and Allen Ferrell, 'On Takeover Law and Regulatory Competition' (2002) 57 Business Lawyer 1047.

108 Martin Gelter, 'The Pension System and the Rise of Shareholder Primacy' (2013) 43 Seton Hall Law Review 909 at 920 .

${ }^{109}$ William W Bratton and Michael L Wachter, 'Shareholder Primacy's Corporatist Origins: Adolf Berle and 'The Modern Corporation' (2008) 34 Journal of Corporation Law 99; Bernard S. Sharfman, 'Shareholder Wealth 
famously embodied in Friedman's claim that the social responsibility of a corporation is to make profits for its shareholders, and shareholder wealth maximisation is the overriding corporate objective.

The weaknesses of Delaware company law from a minority shareholder perspective have been compensated for in other quarters: highly respected listing standards maintained by the NYSE to protect minority shareholders since even before the Securities Exchange Act 1934 and the advent of securities regulation in the 1930s. Seligman ${ }^{110}$ provides an account of the NYSE's historical role in 'maintaining appropriate standards of corporate responsibility, integrity and accountability' to shareholders' in relation to its listed companies. Following the controversial listing of non-voting shares by Dodge Brothers Inc and Industrial Rayon Corporation on the NYSE, the NYSE decided in 1926 to disallow the listing of non-voting shares or shares with unusual voting provisions, effectively upholding a one-share one-vote principle. ${ }^{111}$ This policy established the early reputation of the NYSE as a strong advocate of minority rights.

However, in 1985, the NYSE decided to relax its adherence to the one-share one-vote principle by admitting a number of exceptions. ${ }^{112}$ This softening stance occurred due to competitive pressures from the NASD and AMEX, both of which allowed dual-class voting structures subject to corporate governance safeguards. ${ }^{113}$

Maximization and Its Implementation Under Corporate Law' (2013) 65 Florida Law Review (forthcoming 2013), available at http://ssrn.com/abstract=2198459. The opponents of 'shareholder primacy' advocate a director primacy model that allow directors more objectivity in managing the resources of the corporation and be free of undue shareholder influence, see Margaret Blair and Lynn Stout, "A Team Production Theory of Corporate Law” (1999) 85 Virginia Law Review 248; Stephen M Bainbridge, 'Director Primacy and Shareholder Disempowerment' (2006) 199 Harvard Law Review 1735; Lynn Stout, The Shareholder Value Myth: How Putting Shareholders First Harms Investors, Corporations, and the Public (Berrett-Koehler, 2012).

110 Joel Seligman, 'Equal Protection in Shareholder Voting Rights: The One Common Share, One Vote Controversy' (1986) 54 George Washington Law Review 687.

${ }^{111}$ Seligman recorded two key refusals by the NYSE to list non-voting shares in 1940 and 1976 although differential voting shares were allowed to list in 1956 by Ford Motor Co.

112 (a) the transaction in which the shares with different voting rights are to be issued has been approved by two-thirds of all shares entitled to vote on the proposition; (b) the issuer had a majority of independent directors at the time the matter was voted upon and a majority of such directors approved the proposal; if the issuer had less than a majority of such directors, then all independent directors approved; (c) the ratio of voting differential per share is no more than one to ten; and (d) the rights of the holders of the two classes of common stock are substantially the same except for voting power per share.

${ }^{113}$ NASD required that the listed company appoint at least two independent directors and that an independent audit committee had to be formed; AMEX required that shareholders be allowed to appoint at least two directors to the Board within 2 years of the dual-class listing. 
The relaxation of the one-share one -vote principle by the NYSE was attacked as a retrograde step in several academic quarters ${ }^{114}$. However, other commentators have defended ${ }^{115}$ it and the NYSE has since maintained its relaxation of the one-share one-vote principle. Following their demutalisation and for-profit orientation since 2006, one should be mindful of the scepticism voiced by Karmel ${ }^{116}$ regarding the role of exchanges in watering down governance requirements in order to attract potential issuers. However, exchanges should not assume all of the responsibility for the current state of the minority protection regime. They are subject to the intervention of the Securities Exchange Commission (SEC) in respect of approving, amending or adding to listing rules, to which we now turn. ${ }^{117}$

The SEC was created in 1934 as part of the New Deal in response to an acute need for investor protection on securities markets. ${ }^{118}$ The main regulatory methodology adopted by the SEC was securities disclosure at initial public offers and in continuing obligations. La Porta el al have argued that SEC regulation and civil enforcement are central to the investor appeal of US securities markets. ${ }^{119}$ Further, Coffee opines that SEC enforcement is an attractive factor for investors who find comfort in the SEC-policed framework for investor protection. ${ }^{120}$ A number of commentators have also argued that the brand of stringent securities regulation in the US appeals to investors, motivating firms to cross-list on US stock exchanges if they wish to achieve bonding with those standards. ${ }^{121}$ Firms that bond with

\footnotetext{
${ }^{114}$ Joel Seligman, 'Equal Protection in Shareholder Voting Rights: The One Common Share, One Vote Controversy' (1986) 54 George Washington Law Review 687; Jeffrey N Gordon, 'Ties That Bond: Dual-class Common Stock and the Problem of Shareholder Choice' (1988) 76 California Law Review 1; Manning Gilbert Warren III, 'One Share, One Vote: A Perception of Legitimacy' (1988) 14 Journal of Corporation Law 89.
}

${ }^{115}$ Fischel defended the NYSE trusting in its balance of alternative corporate governance measures as the NYSE had a reputational stake in maintaining an attractive market, see Daniel R Fischel, 'Organized Exchanges and the Regulation of Dual-class Common Stock' (1987) 54 University of Chicago Law Review 119. Dent was of the view that dual-class voting stock was not a serious handicap to takeovers and other defences that exist were far more potent.George W Dent Jnr, ‘Dual-class Capitalization: A Reply to Professor Seligman' (1986) 54 George Washington Law Review 725.

${ }^{116}$ Roberta S Karmel, 'Turning Seats Into Shares: Implications of Demutualization for the Regulation of Stock Exchanges' (2002) 53 Hastings Law Journal 367.

${ }^{117}$ Section 19c-4, Securities Exchange Act 1934, inserted in 1987.

118 Joel Seligman, The Transformation of Wall Street: A History of the Securities and Exchange Commission and Modern Corporate Finance (Michigan: Aspen Publishers, 2003).

${ }^{119}$ R La Porta, F Lopez-de-Silanes and A Shleifer, 'What Works in Securities Laws' (2006) 71 Journal of Finance 1.

120 John C Coffee, 'Law and the Markets- The Impact of Enforcement' (2007) 156 University of Pennsylvania Law Review 229.

${ }^{121}$ John C Coffee, Jnr, 'The Future as History: The Prospects for Global Convergence in Corporate Governance and Its Implications' (1999) 93 Northwestern University Law Review 641; Edward Rock, 'Securities Regulation as Lobster Trap: A Credible Commitment Theory of Mandatory Disclosure' (2002) 23 Cardozo Law Review 675. 
such high investor-protection standards are likely to be rewarded with better market valuation and a broader investor base. However, a number of commentators also point out that the demand for cross-listings in the US could also primarily be due to the depth and liquidity of its capital markets. ${ }^{122}$

In light of the weaknesses of state company law, securities regulation is arguably a major part of the minority shareholder protection landscape in the US. The viability of civil enforcement allows aggrieved investors to seek compensation for disclosure failings or market abuse such as insider dealing. A significant proportion of the minority shareholder protection available to investors in the US is realised through private securities litigation. ${ }^{123}$

However, the SEC, perhaps influenced by the ever-louder voices of the institutional fund management industry, ${ }^{124}$ has increasingly extended its investor protection agenda to the provision of prescriptive corporate governance standards for listed companies, ${ }^{125}$ particularly in terms of the structure and functioning of the board of directors. ${ }^{126}$ In extending its reach into corporate governance, the SEC has faced controversy and challenge. ${ }^{127}$ Does the SEC have a broader mandate ${ }^{128}$ for investor protection which

\footnotetext{
${ }^{122}$ Amir Licht, 'Cross-Listing and Corporate Governance: Bonding or Avoiding?' (2003) 4 Chicago Journal of International Law 141; Andreas Charitou, Christodoulos Louca and Stelios Panayides, 'Cross-Listing, Bonding Hypothesis and Corporate Governance' (2007) 34 Journal of Business Finance and Accounting 1281 and at http://papers.ssrn.com/sol3/papers.cfm?abstract id=949827; Cally Jordan, 'The Chameleon Effect: Beyond the Bonding Hypothesis for Cross-Listed Securities' (2006) at http://papers.ssrn.com/sol3/papers.cfm?abstract id=901768.
}

${ }^{123}$ Steven A Ramirez, 'The Virtues of Private Securities Litigation: An Historic and Macroeconomic Perspective' (2014) 5 Loyola University of Chicago Law Journal 669.

${ }^{124}$ Stephen J Choi, Jill E Fisch and Marcel Kahan, 'The Power of Proxy Advisors: Myth or Reality?' (2010) 59 Emory Law Journal 869 argue that the ISS wields significant corporate governance monitoring powers as it is very influential with institutions.

${ }^{125}$ See Special Study Group of the Committee on Federal Regulation of Securities, American Bar Association, 'Special Study on Market Structure, Listing Standards and Corporate Governance' (2002) 57 Business Lawyer 1487.

${ }^{126}$ Such as in the SEC's enactment of short-lived rule 19c-4 to require a one-share one vote-principle to be maintained by all national exchanges.

${ }^{127}$ Stephen M Bainbridge, 'The Scope of the SEC's Authority over Shareholder Voting Rights' (2007) at http://ssrn.com/abstract=985707; Jill E Fisch, 'The New Federal Regulation Of Corporate Governance' (2004) 28 Harv. J.L. \& Pub. Pol'y 39 arguing that the scope of power vested in the SEC to achieve investor protection in the relevant empowering provisions are rightly and narrowly interpreted by courts so as not to allow broad rhetoric of corporate suffrage to justify the exercise of broad discretion in SEC rule-making.

128 J Robert Borwn Jnr, 'Corporate Governance, the Securities and Exchange Commission, and the Limits of Disclosure' (2007) 57 Catholic University Law Review 45. Also see Robert B Thompson, 'Corporate Federalism in the Administrative State: The Sec's Discretion to Move the Line Between the State and Federal Realms of 
justifies its adoption of prescriptive measures in corporate governance other than imposing disclosure obligations? The SEC is limited by the so-called 'internal affairs doctrine' which favours state company law when legislating on corporate governance matters. ${ }^{129}$ It suffered a major blow to its prescriptive competence in corporate governance in Business Roundtable v SEC in $1990^{130}$ when the DC Circuit struck down as invalid the SEC's requirement forcing all exchanges to adopt a one-share one-vote rule. In $2011^{131}$ the DC Circuit invalidated the SEC's rule ${ }^{132}$ that allowed shareholders to place their nominee candidates to the Board on proxy materials prepared by the issuer. The Court in both instances held that the SEC had no jurisdiction to prescribe corporate governance standards that went beyond the empowering provisions in the Securities Exchange Act 1934 narrowly interpreted to relate only to disclosure obligations for investor protection. The contours of the SEC's powers to prescribe corporate governance standards for investor protection are therefore uncertain.

However, express legislation - often in the wake of corporate or financial crises - can still provide the SEC with power to prescribe corporate governance rules. For example, the Sarbanes-Oxley Act $2002^{133}$ prescribes that national stock exchanges should put in place mandatory listing rules to require all listed companies to have in place an audit committee comprising only of independent directors to be responsible for hiring auditors, ${ }^{134}$ and that financial statements should be signed off by the Chief Executive and Financial Officers. ${ }^{135}$ The Dodd-Frank Act 2010 provides for increased shareholder rights in an advisory vote

Corporate Governance' (2007) 82 Notre Dame Law Review 1143 and Timothy de Lizza, 'The Incoherency of American Corporate Governance and the Need for Federal Standards' (2007) 34 Fordham Urban Law Journal 1111 , both arguing that there is scope for public interest based interventions into corporate governance standards, thereby federalising them.

${ }^{129}$ See Edgar v. MITE Corp., 457 U.S. 624, 645 (1982).

${ }^{130} 905$ F.2d 406 (D.C. 1990).

${ }^{131}$ Business Roundtable and Chamber of Commerce v. Securities and Exchange Commission, No. 10-1305 slip op. (D.C. Cir. Jul. 22, 2011). See critique in Jennifer Connelly, 'How the D.C. Circuit Got it Wrong: The Decision in Business Roundtable v. SEC, SEC's Rule 14a-11 and the Proposal for Increased Shareholder Access to Corporate Proxy Materials' (2011) at http://ssrn.com/abstract=2170507. However Fisch doubts that the proxy access rule would dramatically improve shareholder rights anyway and would lead to dubious consequences in partisan-motivated nominations, see Jill E Fisch, 'The Destructive Ambiguity of Federal Proxy Access' (2012) 61 Emory Law Journal 435.

132 Rule 14a-11.

133 Roberta Romano, 'The Sarbanes-Oxley Act and the Making of Quack Corporate Governance' (2005) 114 Yale Law Journal 1521.

${ }^{134}$ Section 301.

${ }^{135}$ Section 302. 
about executive compensation and golden parachutes, ${ }^{136}$ and prescribes that national exchanges should make mandatory listing rules to put in place claw-back policies regarding executive compensation. ${ }^{137}$

Arguably, the SEC by virtue of the power to approve of, amend or add to stock exchange listing rules ${ }^{138}$ has influenced the corporate governance content of listing rules even when the SEC does not directly prescribe those standards. ${ }^{139}$ SEC influence has therefore become a surrogate channel for corporate governance standards to be set and maintained, ${ }^{140}$ although investors lack the options of civil enforcement which would be available if the standards were prescribed as SEC regulation. For example, the SEC's reforms to Regulation $S-K^{141}$ in 2007, introducing a host of corporate governance disclosures under Item $407^{142}$ have been taken on board by the NYSE which incorporated the corporate governance standards in its listing rules in $2009 .^{143}$

The corporate governance standards maintained by the NYSE tend to be premised upon combating the agency problems arising from a potential misuse of power by professional management, and rely largely upon mandating a significant oversight and monitoring role

\footnotetext{
${ }^{136}$ Section 951, and the relevant SEC release provides that such a vote would be conducted not less frequently than once in every 3 years.

${ }^{137}$ Section 954.

${ }^{138}$ Section 19(b)(7), Securities Exchange Act 1934.

${ }^{139}$ Renee B Jones, 'Does Federalism Matter? Its Perplexing Role in the Corporate Governance Debate' (2007) 41 Wake Forest Law Review 879.

${ }^{140}$ For an early view against listing rules adopting corporate governance standards, see Douglas C Michael, 'Untenable Status of Corporate Governance Listing Standards Under the Securities Exchange Act' (1992) 47 Business Lawyer 1461.

${ }^{141}$ See http://www.law.uc.edu/sites/default/files/CCL/regS-K/SK407.html.

${ }^{142}$ Item 407 requires disclosure of each independent director's identity, criteria applied for determining each director's independence, the total number of Board and Board committee meetings held in the year, the existence or otherwise of a nominating committee, its charter, functions and selection criteria, the existence of otherwise of a compensation committee, its charter, functions and use or otherwise of remuneration consultants, the provisions of the audit committee charter and how the committee has discharged its statutory obligations, and the details of a shareholder communications policy if any.

${ }^{143}$ Section 303A.03 to 303A.10 require all listed companies to have a majority of independent directors, to introduce more stringent independence standards, to require non-executive management meetings to be carried out regularly without management, to institute nominating and compensation committees comprising only of independent directors, to require that audit committees should have at least 3 members who are independent directors and each to be financially literate, to require a binding vote from shareholders for all equity-compensation plans and to adopt and disclose a code of business conduct and ethics for all directors, officers and employees.
} 
for independent board members. ${ }^{144}$ These independence requirements are possibly the most stringent in the world, at least compared to the other two listed markets studied in this article.

However, several of the NYSE corporate governance standards do not apply if a listed company is block-held to $50 \%$ or more. ${ }^{145}$ These are: the requirement to have a majority of independent directors on the Board and to create nominating and compensation committees comprising only of independent directors. This is an interesting limitation of the reach of governance regulation. Perhaps the NYSE regards independent representation on the Board as being less relevant to blockholder-dominated enterprises? It is nonetheless a potential source of concern for minority shareholders in such companies.

The NYSE Listing Rules do not provide many safeguards for minority shareholders of listed companies that feature dual-class voting or concentrated ownership. The Listing Rules contain general principles to prohibit conflicts of interest, misappropriation of corporate opportunities $^{146}$ and director/officer share transactions surrounding corporate communications. ${ }^{147}$ Related-party transactions do not require shareholder voting except where they are issues of securities to the effect of increasing voting power by at least one per cent. ${ }^{148}$ These transactions may be effected after scrutiny by the audit committee. ${ }^{149}$ The NYSE Listing Rules however attempt to ameliorate the disadvantage of holding nonvoting shares in a dual-class structure by prohibiting such shares from further being differentiated in terms of entitlements compared to the other classes of listed shares. ${ }^{150}$ Further, the Listing rules spell out a number of protections for preferred shareholders. Preferred shareholders would have a right to nominate two directors if six defaults of dividend occur that are not compensated for ${ }^{151}$ Preferred shareholders would also be able to vote as a class on new issues of the same security or if a more senior issue is proposed (in which case, a two-third majority is needed for approval). ${ }^{152} \mathrm{~A}$ two-thirds majority vote in the

\footnotetext{
${ }^{144}$ Usha Rodrigues, 'The Feishization of Independence' (2008) 33 Journal of Corporation Law 447.

${ }^{145}$ Section 303A.00.

${ }^{146}$ Under the requirement imposed on listed companies to maintain a Code of Business Conduct and Ethics, section 303A.10.

${ }^{147}$ Section 309.00

${ }^{148}$ Section 312.03

${ }^{149}$ Section 314.00.

${ }^{150}$ Section 313.00(B)

${ }^{151}$ Section 313.00(C).

${ }^{152}$ Above.
} 
preferred stock class is also required to pass any proposed charter or by-law amendments that affect the class. ${ }^{153}$

Given the traditional US context of corporate resistance towards increasing shareholder rights, ${ }^{154}$ it is perhaps not surprising that the NYSE Listing Rules do not feature many specific shareholder protections, particularly in relation to companies with a dual-class voting structure. That said, empirical research ${ }^{155}$ in the US shows that many companies featuring dual-class voting structures have voluntarily put in place mechanisms such as increased independent Board representation to assuage minority concerns. Further, the concerns of minority shareholders may also be mitigated to an extent where the listed market is supported by a landscape of good security analyst coverage.

In sum, securities regulation and its influence upon the corporate governance standards of stock exchange listing rules, along with associated investor litigation possibilities, lie at the core of the investor protection regime in the US. ${ }^{156}$ However, specific standards that address governance issues in blockholder-controlled companies are relatively absent. Furthermore, the NYSE, Nasdaq and AMEX are distinctive in our global comparison of listing regimes in allowing dual-class voting structures which could in principle give rise to minority protection concerns. ${ }^{157}$ What explains this regulatory status quo? We tentatively suggest that the pro-management perspective underlying legislative frameworks in company law, along with the continued prevalence of dispersed ownership in most listed companies, continues to incline investors and regulators towards a focus on the agency problem of over-powerful management, and not towards issues that pertain to the governance of blockholder-controlled companies. Furthermore, the unparalleled commercial success of leading US technology companies, despite (or perhaps because of) their unconventional governance structures, has legitimised a shift away from a regulatory regime that protects minority shareholders in the blockholder context.

\section{Minority Shareholder Protection in the Hong Kong Listing Regime}

\footnotetext{
${ }^{153}$ Above.

154 in particular the Business Roundtable's aggressive lobbying efforts on behalf of the management sector and its successes in court in invalidating pro-shareholder rules enacted by the SEC.

${ }^{155}$ R. Charles Moyer, Ramesh Rao, and Phillip M. Sisneros, 'Substitutes for Voting Rights Evidence from Dual Ciass Recapitaiizations' (1992) Financial Management 35.

${ }^{156}$ Tobias H. Tröger, 'Corporate Governance in a Viable Market for Secondary Listings' (2007) 10 University of Pennsylvania Journal of Business and Employment Law 89 argues that securities regulation has come to brand the US listed markets.

157 John C Coffee Jnr, 'Dispersed Ownership: the Theories, the Evidence, and the Enduring Tension between 'Lumpers' and 'Splitters' (2010) at http://ssrn.com/abstract=1532922.
} 
The primary market for listings in Hong Kong is the Stock Exchange of Hong Kong (SEHK), wholly owned by the listed parent company Hong Kong Exchanges and Clearing Ltd (HKEx). The SEHK is the second largest market by capitalisation in Asia after the Tokyo Stock Exchange.

The SEHK is dominated by blockholder-controlled firms. Domestically incorporated blockheld firms listed on the SEHK are mainly family owned and controlled. ${ }^{158}$ The SEHK is also a favourite listing destination for Chinese companies. Many Chinese-incorporated block-held firms are state-owned and controlled, issuing ' $\mathrm{H}$ ' shares on the SEHK, ${ }^{159}$ including the Bank of China, PetroChina and the Industrial and Commercial Bank of China. Chinese companies can also be incorporated in Hong Kong or elsewhere and list as 'red chips' ${ }^{160}$ on the SEHK while maintaining their businesses largely in China. Two examples of the latter are China Mobile Ltd and Lenovo Group Ltd, both incorporated in Hong Kong.

Commentators have discussed extensively the issue of minority expropriation by controlling shareholders in Hong Kong. Prior to its criminalisation in 2003, controlling shareholders regularly undertook insider dealing ${ }^{161}$ in order to make private gains. This was typically carried out based on insider knowledge around the time of earnings announcements. ${ }^{162}$ Controlling insiders have carried out tunnelling or minority expropriation, such as diversion of company assets to other companies in the group, favourable transactions with related parties or other transactions to extract private benefit. ${ }^{163} \mathrm{~A}$ common practice has been to

\footnotetext{
${ }^{158}$ R La Porta, F Lopez-de-Silanes and A Shleifer, 'Corporate Ownership around the World' (1999) 106 Journal of Finance 471; Simon SM Ho, 'Corporate Governance in Hong Kong: Key Problems and Prospects' (2003) at http://ssrn.com/abstract=440924 points out that over $70 \%$ of listed firms in Hong Kong are block-held by families. Adrian CH Lei and Frank M Song, 'Board Structure, Corporate Governance and Firm Value: Evidence from Hong Kong' (2012) 22 Applied Financial Economics 1289 point out that insiders hold 45\% of stakes in all Hong Kong listed firms. Egs are Cheung Kong Holdings Ltd owned and controlled by Hong Kong billionaire Li KaShing and his family, together with an empire of listed entities which is co-owned by the Holdings company; Li \& Fung Ltd controlled by the Fung brothers, and many others. In fact many of Li's empire of companies is included in the Hang Seng Index.

${ }^{159}$ https://www.hkex.com.hk/eng/stat/smstat/chidimen/cd_hmb.htm.

${ }^{160}$ http://www.hkex.com.hk/eng/stat/smstat/chidimen/cd_rcmb.htm.

${ }^{161}$ pre-2003 and subject to reporting within 5 days of trade.

162 Jun Zhu, Eric C Chang and Michael J Pinegar, 'Insider Trading in Hong Kong: Concentrated Ownership versus the Legal Environment' (2002) at http://papers.ssrn.com/sol3/papers.cfm?abstract id=336702; Man-Yin Cheuk, Dennis K Fan and Raymond W So, 'Insider trading in Hong Kong: Some Stylized Facts' (2006) 14 PacificBasin Finance Journal 73; Mingyi Hung and Robert Trezevan, 'Insider Trading and Corporate Governance Structure: Evidence from Southeast Asia' (2003) at http://ssrn.com/abstract=374422; Bikki Jaggi and Judy Tsui, 'Insider Trading, Earnings Management and Corporate Governance: Empirical Evidence Based on Hong Kong Firms' (2007) 18 Journal of International Financial Management and Accounting 192.
}

${ }^{163}$ Say Goo and Rolf H Weber, 'The Expropriation Game: Minority Shareholders' Protection' (2003) 33 Hong Kong Law Journal 71; Yan-leung Cheung, P Raghavendra Rau and Aris Stouriatis, 'Tunneling, Propping and 
undermine minority rights by dilution when rights offerings are carried out at deep discounts. ${ }^{164}$ At state-owned $\mathrm{H}$-share issuers, the state as controlling insider has hurt minorities by imposing political or socio-economic agendas on the company, such as propping up other ailing state-owned companies or asset- stripping. Such issuers have also been subject to embezzlement by corrupt officers given the weak public governance in China. ${ }^{165}$

However, other commentators have pointed out the benefits of blockholder-controlled companies. Family-owned and controlled companies are often in a good position to take a long-term view of the company's prospects ${ }^{166}$ and to ignore the market noise arising from short-term fluctuations in share prices. ${ }^{167}$ Furthermore, some studies have suggested that family-owned and controlled companies in the region may have better and more sustainable stakeholder relationships. Rather than simply transactional counterparts, stakeholders are viewed by such companies as resources from a resource-dependency point of view. ${ }^{168}$ There is also empirical research ${ }^{169}$ which claims that family-owned and controlled companies have weathered crises better, showing less negative performance and more resilient returns on equity compared to companies with other ownership structures.

The minority shareholder protection regimes in Hong Kong are found in company law, and listing rules pertaining to disclosure and corporate governance standards. The listing regime of the SEHK includes a corporate governance code which applies to issuers on a comply-orexplain basis. ${ }^{170}$ However in 2011, the SEHK enhanced its corporate governance standards

Expropriation Evidence from Connected Party Transactions in Hong Kong' (2004) at http://ssrn.com/abstract=1008780.

${ }^{164}$ Wai Ming Fong and Kevin CK Lam, 'Rights Offerings and Expropriation by Controlling Shareholders' (2014) Journal of Business Finance and Accounting (forthcoming).

${ }^{165}$ Shu-yun Ma, 'Role of the State in Chinese Enterprises Listed in Hong Kong' (2002) 15 The Pacific Review 279.

${ }^{166}$ Hubert Shea, 'Family Firms: Controversies over Corporate Governance, Performance, and Management' (2006) at http://ssrn.com/abstract=934025.

${ }^{167}$ For a discussion on short termism, see The Aspen Institute, 'Short-Termism and US Capital Markets: A Compelling Case for Change' (2010) at http://www.aspeninstitute.org/sites/default/files/content/images/Compelling\%20Case\%20for\%20Change Au gust2010.pdf; BIS, The Kay Review of UK Equity Markets and Long-Term Decision Making (Final Report, 23 July 2012).

${ }^{168}$ Above.

${ }^{169}$ Sidney Leung and Bertrand Horwitz, 'Is Concentrated Management Ownership Value Increasing or Decreasing? Evidence in Hong Kong during the Asian Financial Crisis' (2006) at http://ssrn.com/abstract=984403.

${ }^{170}$ Appendix 14, Rules Governing the Listing of Securities on The Stock Exchange of Hong Kong Limited, at https://www.hkex.com.hk/eng/rulesreg/listrules/mbrules/documents/appendix_14.pdf. 
by making some aspects of corporate governance part of the main Listing Rules and therefore mandatory for listed issuers. ${ }^{171}$

La Porta el al have scored the minority protection regime in Hong Kong favourably, ${ }^{172}$ based on shareholders' company law rights in the Companies Ordinance. ${ }^{173}$ The strong company law rights for minority shareholders in Hong Kong include rights to call a general meeting, ${ }^{174}$ constitutional amendment rights, ${ }^{175}$ anti-director rights such as proxy by mail, ${ }^{176}$ one-share one-vote ${ }^{177}$ rights at capital restructuring and reorganisation, ${ }^{178}$ and minority shareholder remedies. ${ }^{179}$ Directors' duties are further imposed at common law based on English case law precedents. ${ }^{180}$ However, like in the UK, minority shareholder remedies rarely provide real minority shareholder protection on capital markets as litigation is rarely sought. ${ }^{181}$ Some commentators have explained the lack of minority litigation in terms of the Confucian-infused Chinese culture that regards litigation with aversion, preferring informal and harmonious ways of dispute resolution. ${ }^{182}$ Moreover, the derivative action may be forbidding to litigants as a prima facie case has to be proved before the Court before

\footnotetext{
${ }^{171}$ Chapter 3, Stock Exchange of Hong Kong Listing Rules.

${ }^{172}$ Although Hong Kong may seem to be an anomalous example in the general tenor of the thesis that posits that ownership concentration rises with weaker minority protection, see R La Porta, F Lopez-de-Silanes, A Shleifer and R Vishny, 'Law and Finance' (1998) 106 Journal of Political Economy 1113.

${ }^{173}$ Cap 622, available on http://www.legislation.gov.hk/eng/home.htm.

${ }^{174}$ Sections 566, 568, Companies Ordinance.

${ }^{175}$ Section 88, Companies Ordinance.

${ }^{176}$ Section 581, Companies Ordinance.

${ }^{177}$ Section 592 now makes voting on poll the default way to calculate votes, ensuring that all votes by share of capital will be properly counted.

${ }^{178}$ Part 13.

${ }^{179}$ Sections $723-5$, on the unfair prejudice petition; sections 732-7 on the derivative action, Companies Ordinance.

${ }^{180}$ i.e. the fiduciary duty of loyalty, duty to act bona fide in the interests of the company, exercise the powers for their proper purpose, retain their discretionary power, avoid conflicts of interest, and exercise due care, diligence and skill. See Chee Keong Low, 'Is the Standard of Care of Directors Inverted in Hong Kong?' (2008) 38 Hong Kong Law Journal 31.

${ }^{181}$ Paul Spink and Stephen Chan, 'The Hong Kong Company Director's Duty of Skill and Care: A Standard for the 21st Century?' (2003) 33 Hong Kong Law Journal 139 at 164; Horace Yeung and Flora Xiao Huang, 'Law and Finance: What Matters? Hong Kong as a Test Case' (2012) 3 Asian Journal of Law and Economics 1.

${ }^{182}$ Above.
} 
proceeding. ${ }^{183}$ Further, the judicial interpretation of directors' duties seems less stringent than in the UK. The directors' duty to exercise due care, skill and diligence is held in Hong Kong case law to be the same as laid down in Re City Equitable Fire Insurance, ${ }^{184}$ but the UK has since moved on to a more stringent standard of objective competent standards ${ }^{185}$ which takes account of director's qualifications. ${ }^{186}$

Minority shareholder rights, powers and remedies in company law are a regime of law in the books inherited largely from the common law tradition. Yeung et $\mathrm{al}^{187}$ are of the view that these elements of company law inherited from the colonial heritage were essential in creating credibility for Hong Kong as a global listing regime. However, they are not generally utilised in civil enforcement. That said, the SEHK Listing Rules provide guidance for directors in terms of expected conduct, mirroring directors' duties in company law. ${ }^{188}$ Its recent censure of two non-executive directors suggests that exchange-led enforcement could to some degree substitute for weak civil enforcement. ${ }^{189}$

Minority shareholders in Hong Kong may also be protected via disclosure requirements in securities regulation, some of which are found in legislation (the Securities and Futures Ordinance) but most of them in the Listing Rules. The Main Board Listing Rules provide for periodic disclosure of financial information ${ }^{190}$ and half-yearly interim reports ${ }^{191}$ to be made by listed issuers to shareholders, and a general obligation to disclose inside information as reasonably as practicable in order to maintain a fair and orderly market. ${ }^{192}$ The maintenance

\footnotetext{
${ }^{183}$ Lee Aitken, 'Recent Developments in the Shareholder's Derivative Action: Hong Kong and Australian Perspectives' (2009) 39 Hong Kong Law Journal 139, citing Ribeiro PJ in Waddington Ltd v Chan [2008] HKCFA 63.
}

${ }^{184}$ As long as the conduct of the person in question is that of a reasonable director of the same competence, the court will not demand any more of such person, meaning that a minimum objective level of competence is not required. (1925) Ch 407. Applied in Law Wai Duen v Boldwin Construction Co. Ltd [2001] 4 HKC 403.

${ }^{185}$ Re Brian D Pierson (Contractors) Ltd [2001] 1 BCLC 275.

${ }^{186}$ Re Continental Assurance [2001] BPIR 733; Dorchester Finance v Stebbing [1989] BCLC 498.

${ }^{187}$ Horace Yeung and Flora Xiao Huang, 'Law and Finance: What Matters? Hong Kong as a Test Case' (2012) 3 Asian Journal of Law and Economics 1.

${ }^{188}$ Paragraph A.6, Appendix 14, Rules Governing the Listing of Securities on The Stock Exchange of Hong Kong Limited.

${ }^{189}$ See Chee Keong Low, 'Is the Standard of Care of Directors Inverted in Hong Kong?' (2008) 38 Hong Kong Law Journal 32.

${ }^{190}$ Rule 13.46ff, Chapter 13 of the Stock Exchange of Hong Kong Main Board Listing Rules at http://www.hkex.com.hk/eng/rulesreg/listrules/mbrules/documents/chapter_13.pdf.

${ }^{191}$ Rule 13.48ff, above.

${ }^{192}$ Rule $13.05 \mathrm{ff}$, above. 
of a price-efficient market is a key measure of minority shareholder protection for the purposes of exit. ${ }^{193}$ We are of the view that exit has always been of paramount importance to the shareholding community in Hong Kong as passive local investors (almost half of which is institutional and half of which are retail investors) are an important constituent of the ownership base.

Minority shareholders are also protected via regulatory enforcement against market misconduct such as insider dealing. ${ }^{194}$ A recent case suggests that the main financial market regulator, the Securities and Futures Commission (SFC), is increasing the robustness of its market interventions. ${ }^{195}$ Insider dealing prosecutions and civil enforcements have leapt since $2008,{ }^{196}$ coinciding with the increased share-ownership by foreign institutions (dominantly US institutions) of Hong Kong listed equity. It seems that the SFC may be responding to the needs of foreign shareholders, many of whom are institutions used to higher market efficiency standards in the New York and London markets.

According to the HKEx annual surveys, the contribution of local investors to total market turnover decreased steadily from 2009/10 ${ }^{197}$. By end 2012, ${ }^{198}$ overseas investors' contribution at $46 \%$ exceeded the $38 \%$ contributed by local investors. The changes in the ownership landscape of Hong Kong listed equity coincide not only with increased market enforcement but also with developments in corporate governance standards such as in the introduction of independent directors, Board committees and special shareholder rights.

In 2005, the Main Board of the SEHK adopted a corporate governance code subject to a comply-or-explain approach. The Code consists of two levels of recommendations - code provisions which are subject to comply or explain and recommended best practices that are guidelines only. Corporate governance reforms were further consulted upon in 2011 and

\footnotetext{
${ }^{193}$ Horace Yeung and Flora Xiao Huang, 'Law and Finance: What Matters? Hong Kong as a Test Case' (2012) 3 Asian Journal of Law and Economics 1.

${ }^{194}$ Section 245, Securities and Futures Ordinance.

${ }^{195}$ SFC v Tiger Asia Management LLC (unrep., HCMP1502/2009, [2011] HKEC 824) (21 June 2011), commented in Chee Keong Low, Mohan Datwani and Samantha Datwani, 'Pouncing Dragon, Hidden Tiger--A Case of Regulatory Overreach?' [2012] Hong Kong Law Journal 701.

${ }^{196}$ The SFC initiated its first criminal prosecution in 2008 and brought another 10 more in that year, also see high profile successful prosecutions such as HKSAR v Du Jun DCCC 787/2008 where a former Morgan Stanley banker was convicted for insider dealing, and HKSAR v Ma Hon-yeung DCCC 229-240/2008 where a vicepresident of a financial institution and his tippee girlfriend were both convicted.

${ }^{197}$ HKEx's Cash Market Transaction Survey 2009/10 (February 2011), at 2.

${ }^{198}$ HKEx's Cash Market Transaction Survey 2011/12 (February 2013) at 2.
} 
took effect in 2012. These elevate certain corporate governance standards to the status of mandatory listing rules. ${ }^{199}$

The mandatory corporate governance standards that are part of the Listing Rules include the requirement to appoint a third of independent directors to the Board, ${ }^{200}$ to institute an audit committee comprising only of non-executive directors ${ }^{201}$ and to institute a remuneration committee ${ }^{202}$ chaired by an independent director and comprising of a majority of independent directors. The Listing Rules provide a non-exhaustive list of criteria $^{203}$ for independence. ${ }^{204}$

The Code provisions which are subject to comply-or-explain include the separation of the roles of Chairman and Chief Executive, ${ }^{205}$ the institution of a nomination committee, ${ }^{206}$ and facilitating effective shareholder communications and voting at general meetings. ${ }^{207}$ These standards are broadly in line with those included in the UK Corporate Governance Code. The Code provisions also provide for the Board's role in assessing internal controls, ${ }^{208}$ duties of directors, ${ }^{209}$ principles regarding delegation of functions ${ }^{210}$ and supply of information to Boards. $^{211}$

\footnotetext{
${ }^{199}$ These are contained in Chapter 3 of the Main Board's Listing Rules instead of being housed in the Code which is an Appendix to the Listing Rules. Amendments made effective as of 1 January 2012.

${ }^{200}$ Rule 3.10, Chapter 3, Stock Exchange of Hong Kong Main Board Listing Rules.

${ }^{201}$ Rule 3.21, above.

${ }^{202}$ Rule 3.25, above.

${ }^{203}$ Rule 3.13, above.

204 including not having interests in securities in the issuer, not being financially dependent, not having a material interest in the issuer's principal business activities, not having been a director, partner, principal, professional adviser or controlling shareholder, not having connections with the above or being a nominee director and not having been appointed as executive director of the listed issuer within the previous two years. Listed issuers could however appoint a person falling short of the above criteria upon satisfactory explanation to the Exchange that the person concerned could still be regarded as independent.
}

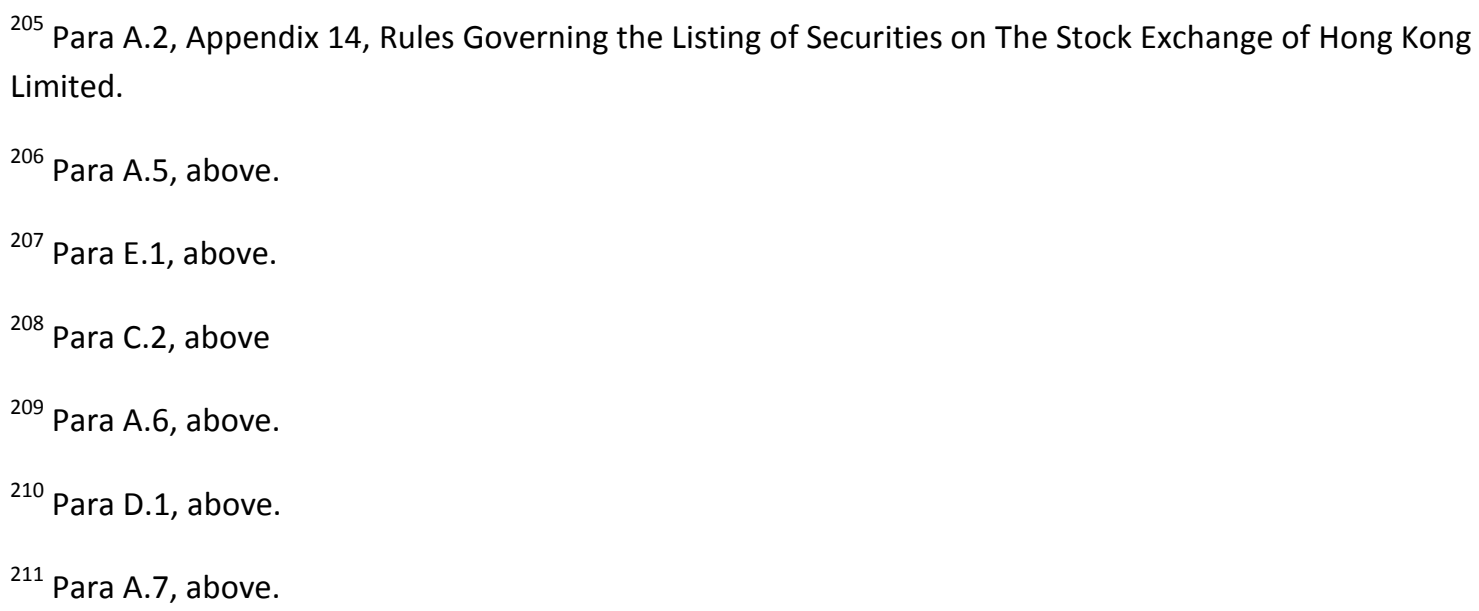


Optional provisions that are framed as best practice include requiring the audit committee to develop a whistle-blowing policy, ${ }^{212}$ the publication of quarterly financial information ${ }^{213}$ and linking executive pay to corporate and individual performance. ${ }^{214}$

In terms of shareholder rights and powers, the Listing Rules prescribe that 'notifiable transactions' need to be disclosed to shareholders, and generally require shareholder approval. ${ }^{215}$ 'Notifiable transactions' include share transactions, discloseable transactions, major transactions, very substantial disposals (or acquisitions) that meet one or more ratio thresholds such as the asset, profit, revenue, capital or consideration ratios as defined in the Listing Rules. ${ }^{216}$

Furthermore, minority shareholders unconnected with blockholders in a company are given special powers where connected transactions are concerned. Certain transactions with connected persons ${ }^{217}$ have to be approved by a majority of independent shareholders. ${ }^{218}$ Connected transactions include acquisitions or disposals of interests in the listed issuer, favourable subscriptions for shares, financial assistance, options granting and joint ventures. ${ }^{219}$ The Listing Rules prescribe the information that needs to be circulated to shareholders, including the advice of an independent financial adviser. ${ }^{220}$ The independent shareholders are defined as being not connected persons or persons not having a material interest in the connected transaction in question. ${ }^{221}$

We observe a coincidence in the rise in the importance of corporate governance standards in Hong Kong with the rise in foreign institutional ownership of Hong Kong listed equity. This seems to suggest that foreign minority shareholders regard corporate governance standards

\footnotetext{
${ }^{212}$ Para C.3.8, above.

${ }^{213}$ Para C.1.6, above.

${ }^{214}$ Para B.1.7, above.

${ }^{215}$ Chapter 14, Stock Exchange of Hong Kong Main Board Listing Rules.

${ }^{216}$ Where share transactions or discloseable transactions are concerned (such as where the listed issuer acquires assets using securities that are publicly traded or where the listed issuer engages in a series of transactions that meet at least $5 \%$ of one of the 5 ratios mentioned above), shareholder approval is not required but disclosure obligations are triggered. Rule 14.33, above.

${ }^{217}$ defined as persons with previous affiliations with the listed issuer, business relations, oversight relations or family relations , Rule 14A.11, Chapter 14A.

${ }^{218}$ Rule 14A.02, above.

${ }^{219}$ Rule 14A.13, above.

${ }^{220}$ Rule 14A.21, above.

${ }^{221}$ Rule 14A.18, above.
} 
as important for minority shareholder protection. Empirical studies on Hong Kong listed issuers shows that independent directors are valued by the capital markets and investors reward these issuers with higher valuations. ${ }^{222}$ There is a body ${ }^{223}$ of empirical research which suggests that Hong Kong issuers that have instituted corporate governance frameworks in accordance with the Listing Rules and Corporate Governance Code enjoy better investor perceptions than their non-complying peers. Sun et $a^{224}$ also find that Chinese ' $\mathrm{H}$ ' share issuers substantively improve their corporate governance practices when listing in Hong Kong, based on an in-depth case study of the Bank of China.

Institutional investors appear to be exerting influence upon investee companies to improve their governance ${ }^{225}$. The appointment of minority shareholder rights activist David Webb ${ }^{226}$ to the Board of the HKEx in 2003 and the profile of annual surveys carried out by $\mathrm{BDO}^{227}$ on the state of corporate governance in Hong Kong suggest that minority institutional concerns are being brought to bear on the SEHK and SFC ${ }^{228}$. The preference for prescriptive corporate governance standards and wider scrutiny of adherence to such standards is certainly on the

\footnotetext{
${ }^{222}$ Adrian CH Lei and Frank M Song, 'Board Structure, Corporate Governance and Firm Value: Evidence from Hong Kong' (2012) 22 Applied Financial Economics 1289.

${ }^{223}$ Yan-Leung Cheung, J. Thomas Connelly, Ping Jiang, and Piman Limpaphayom, ‘Does Corporate Governance Predict Future Performance? Evidence from Hong Kong' (2011) Financial Management 159; Adrian CH Lei and Frank M Song, 'Corporate Governance, Family Ownership, and Firm Valuations in Emerging Markets: Evidence from Hong Kong Panel Data' (2008) at http://ssrn.com/abstract=1100710; Yan-Leung Cheung, J Thomas Connelly, Piman Limpaphayom and Lynda Zhou, 'Do Investors Really Value Corporate Governance? Evidence from the Hong Kong Market' (2007) 18 Journal of International Financial Management and Accounting 86; although some empirical research do not find corporate governance practices aimed at controlling blockholders as being relevant to the long term viability or performance of firms measured by their Tobin qs, see Chandrasekhar Krishnamurti, Aleksandar Sêvic' and Željo Ševic, 'Legal Environment, Firm-level Corporate Governance and Expropriation of Minority Shareholders in Asia' (2005) 38 Economic Change and Restructuring 85.

${ }^{224}$ Laixiang Sun and Damian Tobin, 'International Listing as a Mechanism of Commitment to More Credible Corporate Governance Practices: the case of the Bank of China (Hong Kong)' (2005) 13 Corporate Governance 81.

${ }^{225} \mathrm{Ji}$ Li, Kevin Lam, Gongming Qian and Yongqing Fang, 'The Effects of Institutional Ownership on Corporate Governance and Performance: An Empirical Assessment in Hong Kong' (2006) 46 Management International Review 259.

${ }^{226}$ http://webb-site.com/dbpub/ which tracks proportion of independent directors on Hong Kong listed firms, Board composition and diversity etc.

${ }^{227}$ http://www.bdo.com.hk/web/en/publications/Research/CorporateGovernanceReview.

${ }^{228}$ Resulting in reforms being consulted on HKex, Consultation Conclusions on Review of the Corporate Governance Code and Associated Listing Rules (Oct 2011) and coming into effect on 1 January 2012, see https://www.hkex.com.hk/eng/newsconsul/hkexnews/2011/111028news.htm.
} 
rise in Hong Kong, as the market becomes more attractive to international listings and investors.

The SEHK and SFC seem determined to maintain the level of minority shareholder protection framed by corporate governance standards as well as the 'branding' appeal achieved by the institution of these standards. The determination of the SEHK and SFC not to water down corporate governance standards was particularly apparent in the recent episode involving the proposed flotation of Alibaba.com in Hong Kong. ${ }^{229}$

The loss of Alibaba.com's potential listing in Hong Kong due to a failure to agree on an acceptable governance structure between issuer and regulator has caused fury in the investment and professional services industries due to the loss of fee revenues such flotation would have generated. SEHK in response has decided to consult on the way forward for its corporate governance standards. ${ }^{230}$ However, institutional investors are firmly supportive ${ }^{231}$ of maintaining existing standards. The buy-side in Hong Kong will be crucial in sustaining a level of minority shareholder protection characterised by wellaccepted ex ante corporate governance standards.

In this brief study of the Hong Kong listing regime, we observe that traditional 'law in the books' valued by La Porta et al (in research dating back almost 15 years), i.e. in the areas of company law rights, do not seem to be the places where minority shareholders find their protection being realised. Securities regulation has since the advent of the Securities and Futures Ordinance and increased empowerment of the SFC ${ }^{232}$ been more relevant to investor protection in (a) sustaining corporate disclosure obligations; (b) cracking down against market abuse and (c) introducing corporate governance standards as part of the listing regime. The rise of foreign institutional ownership of Hong Kong listed equity seems to have exerted significant influence upon reforms in regulatory enforcement against insider dealing and the development of corporate governance standards in listing rules.

Minority expropriation problems have been a long-running feature in the block-held corporate economy in Hong Kong, but it is interesting to observe that the SEHK has adopted

\footnotetext{
${ }^{229}$ Alibaba.com, one of China's largest e-commerce business, is planning to list on the New York Stock Exchange in late-2014 in one of the largest initial public offers in the world, at US\$20 billion. It reportedly sought an exemption from the SEHK from the one-third rule with regard to appointing independent directors and wished to institute a system whereby the founding shareholders, in a partnership structure, would have the exclusive rights to appoint directors. The exemption was rejected by the HK listing authorities. Since then, Alibaba.com has expressed its intention to list on a US exchange which allows dual-class share structures. 'HKEx to Alibaba: Thanks but No Thanks', The Wall Street Journal (25 Sep 2013).

230 'HKEx Mulls Consultation on Shareholding Structures', South China Morning Post (30 Oct 2013).

231 'Fund Managers Against Hong Kong Easing Listing Rules', Financial Times (15 April 2014).

${ }^{232}$ Since 1989 but the new SFO came into force in 2003.
} 
both the strategies of adhering to generic best standards as well as tailor-made rules. The key generic best practice adopted is in ensuring the quantity and quality of independent directors on Boards. It seems that even in the predominantly block-held landscape in Hong Kong, similar standards are seen as applicable in mitigating the principal-principal agency problems.

However, it is important that the development of such standards is not a matter of mere transplantation but is considered within the unique business contexts, and pros and cons of block-held governance structures in Hong Kong. That said, unique Hong Kong solutions in providing for minority shareholder rights such as in notifiable and connected transactions have arguably been developed in a way sensitive to the Hong Kong market. Further, blockholder expropriation is mitigated by making voting by poll mandatory and requiring independent shareholder approval of connected transactions.

\section{Final Observations and Conclusions}

Our review of three major listing regimes suggests that minority shareholder protection frameworks are vibrant and evolving, but company law regimes have become less relevant to such frameworks compared to developments in securities regulation. Company law frameworks for minority shareholder protection in the UK and Hong Kong are well regarded in terms of anti-director rights and shareholder powers, but civil enforcement is largely illusory. In the US, minority shareholder powers are comparatively weak and Delaware company law in particular is significantly pro-director.

However, these relative strengths and weaknesses in company law frameworks have not affected stock market development pronouncedly. The US and UK remain the favourite investor destinations for listed equity ${ }^{233}$ and Hong Kong is a very vibrant market in the AsiaPacific. ${ }^{234}$ It may be argued that 'company law' does not matter, or does not matter significantly. A more optimistic interpretation is that the company law frameworks continue to support a minimum branding appeal even if there is negligible investor reliance on them.

Securities regulation regimes in all three jurisdictions have become more important than company law for developing minority shareholder protection. In particular, all three jurisdictions are broadly convergent along high standards of corporate transparency, timely disclosure and regulatory enforcement for maintaining market fairness and efficiency. In

\footnotetext{
233 'Equities Draw Institutional Investors', The Financial Times (17 April 2014) where a poll of 83 institutions carried out by ING Investment shows a third of them citing the US as a preferred listed market and a quarter of them citing the UK as a preferred listed market.

${ }^{234}$ Horace Yeung and Flora Xiao Huang, 'Law and Finance: What Matters? Hong Kong as a Test Case' (2012) 3 Asian Journal of Law and Economics 1.
} 
addition, there is a tradition of vibrant private securities litigation in the US $\mathrm{S}^{235}$ which can be employed against failings in corporate disclosure and insider dealing. There is also a marked increase in enforcement against insider dealing by authorities in the US, ${ }^{236}$ UK and Hong Kong. The prospect of fair and efficient exit on stock markets seems to be important to institutional investors, and we conclude that 'securities regulation matters' to the appeal and branding of a listing regime. In global securities markets, investor protection is increasingly regarded as a public good provided in securities regulation instead of contractarian arrangements- a fundamental conception that still underlies company law- ${ }^{237}$

A key finding from our study is the increased importance of corporate governance standards, developed as part of the framework of listing rules (and arguably securities regulation), in all three jurisdictions. A mixture of reasons explains the appeal of corporate governance standards - particularly their potential to provide ex ante oversight of corporate behaviour ('defensive' reasons) and as a means of facilitating shareholder engagement and activism ('offensive' reasons). ${ }^{238}$

Corporate governance standards can be adopted as law, such as in the US Sarbanes-Oxley Act $2002,{ }^{239}$ or more usually in listing rules that are contractually mandatory for listed issuers, ${ }^{240}$ but not treated as part of regulatory law. We observe that corporate governance standards developed in all three jurisdictions have tended to become more prescriptive over time. ${ }^{241}$ This trend raises the question as to the legal nature of listing rules ${ }^{242}$ and the long-

\footnotetext{
${ }^{235}$ R La Porta, F Lopez-de-Silanes and A Shleifer, 'What Works in Securities Laws' (2006) 71 Journal of Finance 1.

${ }^{236}$ Such as former New York Attorney-General Eliot Spitzer's crackdown on insider dealing and white collar crime in general where the SEC has failed to pursue such cases.

${ }^{237}$ Coase's 'Nature of the Firm' (1937) 4(16) Economica 386-405 remains the foundation for contractarianism, see exposition in William A Klein, "The Modern Business Organization: Bargaining Under Constraints" (1982) 91 Yale Law Journal 1521; Fred McChesney, "Contractarianism Without Contracts? Yet Another Critique Of Eisenberg" (1990) 90 Columbia Law Rev 1332; Manuel A Utset, "Towards a Bargaining Theory of the Firm" (1995) 80 Cornell Law Review 540; Frank H Easterbrook and Daniel R Fischel, "The Corporate Contract" in The Economic Structure of Corporate Law (Cambridge Mass: Harvard University Press 1991) at 1ff; David Charny, "Hypothetical Bargains: The Normative Structure Of Contract Interpretation" (1991) 89 Michigan Law Review 1815; Stephen Bainbridge, "Community and Statism: A Conservative Contractarian Critique of Progressive Corporate Law Scholarship" (1997) 82 Cornell Law Review 856.

${ }^{238}$ See Iris H-Y Chiu, The Foundations and Anatomy of Shareholder Activism (Oxford: Hart, 2010) on offensive and defensive forms of activism.

${ }^{239}$ Pub.L. 107-204.

${ }^{240}$ the UK Corporate Governance Code for example.

${ }^{241}$ Luigi Zingales, 'The Future of Securities Regulation' (2009) 47 Journal of Accounting Research 391.

${ }^{242}$ Whether listing rules should amount to law. Hall $v$ Cable and Wireless PIc [2009] EWHC 1793 (Comm) in the UK seems to suggest that listing rules are not law since they are not regarded as regulatory law. In Hong Kong,
} 
term prospects for soft law approaches to corporate governance, ${ }^{243}$ as corporate governance standards become increasingly integral to modern securities regulation. There seems to be a significant buy-side underpinning of greater prescription. ${ }^{244}$ Global assets under management total $\$ 64$ trillion according to a survey carried out by Price Waterhouse Coopers $^{245}$ and are forecast to swell to $\$ 102$ trillion by 2020. Global assets under management will increasingly dwarf any individual country's GDP and the investment management sector is increasingly powerful in influencing the terms upon which investments are made, including in equity and securities markets. Demands for robustly implemented governance standards in listed issuers are one manifestation of institutional investors' preferences and these will likely grow. ${ }^{246}$

Broad patterns of international convergence can be found in corporate governance standards that address the agency problem of overly-powerful management in widely-held companies.. ${ }^{247}$ In particular, independent Board representation has become a key building

New World Development Co., Ltd. v. Stock Exchange of Hong Kong Ltd (2005) CACV 170 of 2004, at 34, available at http://legalref.judiciary.gov.hk decided at lower court thought that the application of listing rules in a disciplinary committee constituted by the Exchange was in a 'court' context, thereby also suggesting that the listing rules could have a law-like character. This view was ultimately rejected by the Court of Final Appeal which said listing rules had contractual character only. However, as regulators have a strong influence on listing rules in the US and Hong Kong, and the FCA in the UK is in fact the Listing Authority, there is a point to be made querying the nature of listing rules and the increasingly prescriptive corporate governance standards developed under their auspices.

${ }^{243}$ This is a question the authors are highly interested in exploring in but will not do so here due to constraints of space.

244 J P Hawley and A T Williams, 'Shifting Ground: Emerging Global Corporate-Governance Standards and the Rise of Fiduciary Capitalism' (2005) 37 Environment and Planning 1995; Stuart L Gillan and Laura T Starks, 'Institutional Investors, Corporate Ownership and Corporate Governance: Global Perspectives' (2003) 22 Journal of Applied Finance 134.

245 PwC, Asset Management 2020: A Brave New World (2014) at http://www.pwc.com/us/am2020.

${ }^{246}$ There is much empirical evidence on the increased valuation of companies on securities markets driven by investor preferences where good corporate governance is instituted. See Fabio Bertoni, Michele Meoli, and Silvio Vismara, 'Board Independence, Ownership Structure and the Valuation of IPOs in Continental Europe' (2014) 22 Corporate Governance 116; Lawrence D Brown and Marcus L Caylor, 'Corporate Governance and Firm Valuation' (2009) 25 Journal of Accounting and Public Policy 409 (arguing that there are only a few cherished corporate governance notions that make a difference eg independent directors); Kee $\mathrm{H}$ Chung and Hao Zhang, 'Corporate Governance and Institutional Ownership' (2011) 46 Journal of Financial and Quantitative Analysis 247; Armand Picou and Michael J Rubach, 'Does Good Governance Matter to Institutional Investors? Evidence from the Enactment of Corporate Governance Guidelines' (2006) 65 Journal of Business Ethics 55.

${ }^{247}$ Such as the institutionalisation of independent Board representation and the independent audit committee of the Board, see Paul Davies and Klaus J Hopt, 'Boards in Europe: Accountability and Convergence' (2013) 61 American Journal of Comparative Law 301. 
block in corporate governance standards. Such convergence is arguably driven by the dominant influence of the Anglo-American institutional fund management sector. ${ }^{248}$ Empirical literature has measured convergence in corporate governance standards internationally and records that notable convergence has taken place in standards that are particularly valued for minority shareholder protection. ${ }^{249}$ However, regional fragmentations in corporate governance standards ${ }^{250}$ show that the dialectics of contention between issuers, investors and policy-makers will continue to sustain some of the unique differences in corporate governance standards upheld in each securities market. ${ }^{251}$

What standards ought to be employed to deal with the governance issues of blockholdercontrolled companies is still very much a developing issue, despite the fact that the majority of companies in the world are block-held rather than widely held. ${ }^{252}$ The dynamic growth in the corporate sector in many emerging economies will bring more block-held companies to the world stage. ${ }^{253}$ Many of these companies will have evolved out of state ownership or

\footnotetext{
248 Earlier literature on convergence driven by institutions are more broad-brush and optimistic, see Michael Useem, Investor Capitalism (NY: Basic Books 1999). See the strand of literature on nuanced forms of and drivers for convergence in corporate governance standards, T Yoshikawa and AA Rasheed, 'Convergence of Corporate Governance: Critical Review and Future Directions,' (2009) 17 Corporate Governance: An International Review 388-404; Ilir Haxhi and Ruth V. Aguilera, 'Are Codes Fostering Convergence in Corporate Governance? An Institutional Perspective' (2011) at

http://papers.ssrn.com/sol3/papers.cfm?abstract id=2026352, also ch11, T Yoshikawa and AA Rasheed (eds), Convergence in Corporate Governance: Promise and Prospects (Abingdon: Palgrave Macmillan 2012). Gerald Davis and Christopher Marquis, 'The Globalization of Stock Markets and Convergence in Corporate Governance' (2003) at http://www.economyandsociety.org/wp-content/uploads/2013/08/wp7.pdf; Weil Gotshal and Manges, Comparative Study Of Corporate Governance Codes Relevant to the European Union and Its Member States (2002) at http://ec.europa.eu/internal market/company/docs/corpgov/corp-gov-codes-rptpart1 en.pdf (pointing out significant convergence in Codes although not in company law).
}

${ }^{249}$ Mathias Siems, 'Convergence in Corporate Governance: A Leximetric Approach' (2010) 35 Journal of Corporation Law 729; Carsten Gerner-Beuerle, 'Determinants of Corporate Governance Codes' (2014) at http://papers.ssrn.com/sol3/papers.cfm?abstract_id=2346673.

${ }^{250}$ Carsten Gerner-Beuerle, 'Determinants of Corporate Governance Codes' (2014) at http://papers.ssrn.com/sol3/papers.cfm?abstract_id=2346673.

${ }^{251}$ Detailed studies can be found in T Yoshikawa and AA Rasheed (eds), Convergence in Corporate Governance: Promise and Prospects (Abingdon: Palgrave Macmillan 2012).

${ }^{252}$ See Randall K Morck (ed), Concentrated Corporate Ownership (University of Chicago Press, 2000); A History of Corporate Governance around the World (University of Chicago Press, 2005).

${ }^{253}$ McKinsey Global Institute, Urban World: The Shifting Global Business Landscape (Oct 2013) at http://www.mckinsey.com/insights/urbanization/urban_world_the_shifting_global_business_landscape. 
family ownership ${ }^{254}$, and will wish to gain exposure to global equity markets. The buy-side with rising global assets under management will also feel increasingly pressured to find opportunities for investment and yield. Regulators will have to respond to the accelerating collision of these two very different business cultures.

The slowness to-date in developing standards for block-held companies is probably due to the dominance of Anglo-American corporate governance frameworks based on the widelyheld structure. Such an unrepresentative but dominant view of corporate governance is arguably sustained (a) ideologically and academically in the finance perspective of economies featuring many widely-held large corporations, and (b) by institutional demands, notably those made by Western institutions and asset managers used to corporate governance standards in dispersed ownership economies.

Dealing with the unfortunate experiences of ENRC, Bumi and Essar Energy has given the FCA the opportunity to determine what corporate governance standards should be introduced in order to deal with blockholder-controlled companies and whether soft law is the appropriate medium. The introduction of the Enhanced Listing Regime is measured and incremental in nature. Perhaps tailored and more prescriptive governance standards may be more appropriate for block-held structures. ${ }^{255}$ By partitioning a separate Regime for issuers with controlling shareholders, the FCA has arguably rejected a one-size-fits-all approach in setting corporate governance standards by catering for the unique needs of minority shareholders in block-held companies. In this way, the overall status and nature of the UK Corporate Governance Code is also maintained for the dominant quarter of widely-held companies in the equity market. We support this approach, and would not favour any wholesale shift towards integrating or harmonising corporate governance standards across all ownership structures and market sectors or the over-standardisation of corporate governance through regulation.

Negative perceptions of block-held companies have not emerged to the same extent in the US, which appears comfortable, for now, with the blockholder-dominated control structures of some of its most successful technology companies. In contrast, Hong Kong has long been aware of the dangers of blockholder expropriation, given the prevalence of concentrated ownership in its domestic issuers, with the result that it already incorporates a range of shareholders powers (related to significant and related party transactions) in its listing rules.

\footnotetext{
${ }^{254}$ See for eg Tarun Khanna and Yishay Yafeh, 'Business Groups in Emerging Market- Paragons or Parasites?' (2005) at http://cei.ier.hit-u.ac.jp/activities/seminars/papers/yafeh\%2005.pdf; Mauro F Guillen and Esteban Garcia-Canal, Emerging Markets Rule (NY: McGraw-Hill Professional, 2012).

${ }^{255}$ Also see see Victor Zitian Chen, Jing Li and Daniel M Shapiro, 'Are OECD-prescribed "Good Corporate Governance Practices" Really Good in an Emerging Economy?' (2011) 28 Asia Pacific Journal of Management 115.
} 
The UK's Enhanced Listing Regime should be viewed as a pioneering but experimental framework. Our hope is that as it evolves, policy makers will take a balanced view of the pros and cons of block-held structures. ${ }^{256}$ The governance fiascos of Bumi, ENRC and Essar Energy have been a painful experience for the UK equity market. But we hope that they will not blind the UK to the benefits of an ownership structure which, in an appropriate institutional context, can offer economic opportunities as well as risks.

\footnotetext{
${ }^{256}$ For example see Pablo Martin de Holan and Luiz Sanz, 'Protected by the Family? How Closely Held Family Firms Protect Minority Shareholders' (2006) 59 Journal of Business Research 356. Further, research in Canada also point out that companies with dual-class voting shares which aim to protect the controlling shareholder's interest do not destroy shareholder value over the long term, see Vijay Jog, PengCheng Zhu, and Shantanu Dutta, 'Impact of Restricted Voting Share Structure on Firm Value and Performance' (2010) 18 Corporate Governance 415. There is literature that take a more cautious position on block-held structures or controlling voting rights in dual-class structures, see for example Mike Burkhart and Samuel Lee, 'The One Share - One Vote Debate: A Theoretical Perspective' (2007) at http://ssrn.com/abstract id=987486; Craig Doidge, G Andrew Karolyi, Karl V Lins, Darius P Miller, Rene M Stulz, 'Private Benefits of Control, Ownership, and the Cross-Listing Decision' (NBER Research Paper 2005).
} 